\title{
Lower Phosphoinositide 3-Kinase (PI 3-kinase) Activity and Differential Expression Levels of Selective Catalytic and Regulatory PI 3-Kinase Subunit Isoforms in Prefrontal Cortex and Hippocampus of Suicide Subjects
}

\author{
Yogesh Dwivedi*,', Hooriyah S Rizavi', Tara Teppen', Hui Zhang', Amal Mondal', Rosalinda C Roberts', \\ Robert R Conley ${ }^{3}$ and Ghanshyam N Pandey' \\ 'Psychiatric Institute, Department of Psychiatry, University of Illinois at Chicago, Chicago, IL, USA; ${ }^{2}$ Department of Psychiatry, University \\ of Alabama at Birmingham, Birmingham, AL, USA; ${ }^{3}$ Maryland Psychiatric Research Center, Baltimore, MD, USA
}

Phosphoinositide 3 (PI 3)-kinase is one of the key signaling enzymes that participates in a myriad of physiological functions in brain and is utilized by neurotrophins to mediate neuronal plasticity, cell survival, and inhibition of apoptosis for several neuronal subtypes. Our recent demonstration that expression of neurotrophic factors and activation of the receptor tyrosine kinase B are significantly altered in postmortem brain of suicide subjects led us to examine whether suicide brain is associated with alterations in PI 3-kinase signaling. In prefrontal cortex (PFC), hippocampus, and cerebellum of suicide $(n=28)$ and nonpsychiatric control $(n=21)$ subjects we examined catalytic activation of PI 3-kinase, and mRNA and protein levels of regulatory $(p 85 \alpha, p 85 \beta)$ and catalytic $(p|| 0 \alpha, p|| O \beta)$ subunits of PI 3-kinase. It was observed that the catalytic activity of PI 3-kinase was significantly reduced in PFC and hippocampus of suicide subjects compared with nonpsychiatric control subjects. Competitive PCR analysis revealed significantly reduced mRNA expression of p $85 \beta$ and p I I $0 \alpha$ and increased expression of p85 $\alpha$ subunit isoforms in PFC and hippocampus of suicide subjects. Alterations in these catalytic and regulatory subunits were accompanied by changes in their respective protein levels. These changes were not present in cerebellum of suicide subjects. Also, these changes were present in all suicide subjects irrespective of psychiatric diagnosis. Our findings of reduced activation and altered expression of specific PI 3-kinase regulatory and catalytic subunit isoforms demonstrate abnormalities in this signaling pathway in postmortem brain of suicide subjects and suggest possible involvement of aberrant PI 3-kinase signaling in the pathogenic mechanisms of suicide.

Neuropsychopharmacology (2008) 33, 2324-2340; doi: I0.I038/sj.npp. I 30 I64I; published online I2 December 2007

Keywords: PI 3-kinase; human postmortem brain; suicide; depression; gene expression; immunolabeling

\section{INTRODUCTION}

Phosphoinositide (PI) signaling has become a very important part of signal transduction research. PI 3-kinases are a subfamily of lipid kinases that phosphorylate the three-dimensional position of the inositol ring of PI generating second messengers that are involved in many physiological functions, including cell proliferation, cell survival, cell morphology, synaptic plasticity, protein synthesis, and membrane trafficking (Lin et al, 2001; Cantley, 2002; Rodgers and Theibert, 2002; Wymann et al,

*Correspondence: Dr Y Dwivedi, Psychiatric Institute, Department of Psychiatry, University of Illinois at Chicago, 1601 West Taylor Street, Chicago, IL 60612, USA, Tel: + 312413 4557, Fax: + 3123553857 , E-mail: ydwivedi@psych.uic.edu

Received 5 July 2007; revised 22 October 2007; accepted 25 October 2007
2003; Downes et al, 2005; Downward, 2004; Engelman et al, 2006).

PI 3-kinase proteins have been divided into three classes that differ in structure, substrate specificity, tissue distribution, and in functions. These are termed classes IA/IB, II, and III. Among them, the most important PI 3-kinases are those that belong to the subclass IA, because it is these kinases that are activated by extracellular stimuli, such as neurotrophic and other growth factors, via receptors with intrinsic protein tyrosine kinase (Trk) activity (Fruman et al, 1998; Segal, 2003). Activation of PI 3-kinase leads to the generation of PI-3,4,5- $\mathrm{P}_{3}$ from PI-4, 5- $\mathrm{P}_{2}$ (Hawkins et al, 1992). PI-3,4,5- $\mathrm{P}_{3}$ serves as a critical second messenger and participates in physiological functions.

Subclass IA PI 3-kinase enzymes are heterodimers composed of a catalytic subunit of $110 \mathrm{kDa}$ and an adapter regulatory p85 subunit (Hiles et al, 1992; Hu et al, 1993). 
Three separate genes, $P I K 3 C A, P I K 3 C B$, and $P I K 3 C D$, encode the class IA catalytic subunit, denoted $\mathrm{p} 110 \alpha$, $\mathrm{p} 110 \beta$, and $\mathrm{p} 110 \delta$, respectively. Of these, $\mathrm{p} 110 \alpha$ and $\mathrm{p} 110 \beta$ are abundant in brain, whereas $\mathrm{p} 110 \delta$ is restricted to leukocytes. Three genes, PIK3R1, PIK3R2, and PIK3R3, encode the $\mathrm{p} 85 \alpha, \mathrm{p} 85 \beta$, and $\mathrm{p} 55 \gamma$ isoforms of the $\mathrm{p} 85$ regulatory subunit, respectively (Vanhaesebroeck et al, 2005; Engelman et al, 2006). The PIKR31 gene can also give rise to two smaller regulatory subunits, $50 \alpha$, and $55 \alpha$, but less is known about their specific regulatory features. $\mathrm{p} 85 \alpha$ and $\mathrm{p} 85 \beta$ have wide tissue distribution, whereas $\mathrm{p} 55 \gamma$ shows restricted tissue expression.

Association of the p110 catalytic subunit with p85 regulatory subunits is critical for PI 3-kinase activation by Trk receptors. The catalytic p110 subunits possess an $\mathrm{N}$-terminal p85-binding domain, a Ras binding domain, a C2 domain, a PI kinase domain, and a C-terminal catalytic domain. p85 is composed of an N-terminal Src homology 3 (SH3) domain, a breakpoint cluster-region homology (BH) domain flanked by two proline-rich regions, and two C-terminal SH2 domains. Upon stimulation by growth factors, the SH2 domains of p85 bind to phosphorylated tyrosine in a YxxM motif ( $\mathrm{Y}$ is phosphorylated tyrosine and $\mathrm{X}$ is amino acid), present in many receptor Trks and their substrates (Songyang et al, 1993). This binding relieves the inhibition of p110 and mediates recruitment of the catalytic subunit to the plasma membrane (Okkenhaug and Vanhaesebroeck, 2001). PI-3,4,5- $\mathrm{P}_{3}$, formed in response to the phosphorylation of $\mathrm{PI}-4,5-\mathrm{P}_{2}$, then recruits proteins that contain a pleckstrin homology $(\mathrm{PH})$ domain to the plasma membrane. Along with the direct recruitment of PI 3-kinase, many Trks also recruit adapter proteins, such as Shc, Grb2, Gab-1, via phosphorylated tyrosine residues in the receptor (Kaplan and Miller, 2001; Patapoutian and Reichardt, 2001). Some of these adapters bind the $\mathrm{SH} 2$ domains in the 85 regulatory subunit and recruit PI 3-kinase to the plasma membrane. These adapter complexes can activate PI 3-kinase.

Recently we demonstrated that expression levels of brainderived neurotrophic factor (BDNF) and its cognate receptor TrkB are significantly reduced in prefrontal cortex (PFC) and hippocampus of suicide subjects (Dwivedi et al, 2003a). In addition, we observed that expression of other neurotrophins, such as neurotrophin (NT)-3, NT-4/5, and $\mathrm{NGF}$, is also abnormal in postmortem brain of suicide subjects (Dwivedi et al, 2005a). Since many physiological functions, including prosurvival effects of neurotrophins, occur through the activation of PI 3-kinase (Yao and Cooper, 1995; Crowder and Freeman, 1998; Hetman et al, 1999; Liot et al, 2004), it is important to examine whether this signaling system is altered in postmortem brain of suicide subjects and therefore plays any role in the pathophysiologic mechanisms of suicide. A recent study indicates that the catalytic activity of PI 3-kinase is decreased in occipital cortex of suicide subjects (Hsiung et al, 2003), which suggests the possible involvement of PI 3-kinase in suicide. The present study was undertaken to comprehensively investigate PI 3-kinase signaling in postmortem brain of suicide subjects with and without a history of major depression. To this end, we examined the mRNA and protein expression of various catalytic and regulatory subunits of PI 3-kinase, as well as PI 3-kinase catalytic activity, in PFC, hippocampus, and cerebellum of suicide subjects. We chose these brain areas because the PFC and hippocampus play important roles in mood regulation (George et al, 1994) and cognition (Sweatt, 2004), respectively, and have been implicated in suicide (Rajkowska, 1997; Dwivedi et al, 2003a, 2005a, 2006). Moreover, the hippocampus is the primary brain area affected by stress (Sala et al, 2004), one of the major factors in suicidal behavior (Clayton, 1985; Monk, 1987). We selected the cerebellum because this brain area is largely unaffected in depression and suicide.

\section{MATERIALS AND METHODS}

\section{Subjects}

The study was performed in PFC (Brodmann's area 9, BA9) and hippocampus obtained from suicide subjects $(n=28)$ and nonpsychiatric control subjects $(n=21)$, hereafter referred to as normal controls. Brain tissues were obtained from the Maryland Brain Collection at the Maryland Psychiatric Research Center, Baltimore, MD. After removal from the cranium, the brains were cut into six major pieces (four cerebral cortical lobes, basal ganglia-diencephalon, and lower brain stem-cerebellum), rapidly frozen on dry ice, and stored at $-70^{\circ} \mathrm{C}$ until dissection. During dissection, the frontal lobes were sliced into $1-1.5 \mathrm{~mm}$ thick coronal sections at a temperature between 0 and $10^{\circ} \mathrm{C}$. To keep the samples frozen, the dissections were performed on a metal plate over a container filled with dry ice. The PFC samples were cut out of the coronal sections by a fine microdissecting (Graefe's) knife under a stereomicroscope with low magnification. The dorsomedial PFC (Brodmann's area 9) was taken just dorsal to the frontopolar area including the most polar portion of the superior and partly the middle superior gyrus between the superior and intermediate frontal sulci. In the sections of the dissected cortical area, the gray and white matters were separated, and the gray matter was used in this study. The hippocampus was isolated by blunt dissection into the lateral ventricles to demonstrate the hippocampus at the floor of the lateral ventricle. Before freezing the rest of the temporal lobe, the hippocampus was removed by cutting through the line of the fimbria and including CA1-4 and dentate gyrus. We used $80-100 \mathrm{mg}$ of PFC or hippocampus for performing western blot and determining catalytic activity and an additional $100 \mathrm{mg}$ of tissue to determine mRNA levels. To ensure that the same area was used for each assay, after dissection, each brain area tissue was cut into very small pieces, mixed, and then used for analysis.

All tissues from normal controls and suicide subjects were screened for evidence of neuropathology by experienced neuropathologists. The presence of Alzheimer's disease, infarcts, demyelinating diseases, or atrophy (or clinical history of these disorders) disqualified subjects from the study. Blood/urine samples from every suicide and control subject were systematically obtained. These biological specimens allow the undertaking of a systematic toxicology screening for alcohol and a comprehensive battery for illicit drug use, as well as screening for antidepressant/psychoactive drugs taken prior to death. 
This information, along with the medication history (obtained from hospital records) and the compliance history (obtained through interviews with family members), identifies individuals who have taken antidepressants, psychoactive drugs, or substances of abuse prior to suicide. Subjects who showed alcohol and/or cocaine in blood or urine in the toxicology and are indicated as drug/alcohol abusers in Table 2 were dependent on these drugs. Suicide subjects who were not dependent on drugs or alcohol and showed alcohol/cocaine only during toxicology screening are not indicated as alcohol- or drug abuse-dependent.

In each case, screening for the presence of HIV was done in blood samples, and all HIV-positive cases were excluded. The $\mathrm{pH}$ of the brain was measured in the cerebellum in all cases as described by Harrison et al (1995).

\section{Diagnostic Methods}

At least one family member, after giving verbal informed consent, underwent an interview based on the Diagnostic Evaluation After Death (DEAD) (Salzman et al, 1983) and the Structured Clinical Interview for the DSM-IV (SCID) (Spitzer et al, 1995). The interviews were conducted by a trained psychiatric social worker. Two psychiatrists independently reviewed the write-up from this interview, as well as the SCID that was completed from it, as part of their diagnostic assessment of the case. Their diagnoses were made from the data obtained in this interview, medical records from the case, and records obtained from the Medical Examiner's office. The two diagnoses were compared and discrepancies were resolved by means of a consensus conference. Controls were verified as free from mental illnesses using these consensus diagnostic procedures. This study was approved by the Institutional Review Board of the University of Illinois at Chicago.

\section{Preparation of Tissue}

Tissues were homogenized in lysis buffer containing $20 \mathrm{mM}$ Tris-HC1 (pH 7.4), $150 \mathrm{mM} \mathrm{NaC1}, 1 \mathrm{mM}$ EGTA, $1 \%$ Triton X-100, phosphatase inhibitors $(2.5 \mathrm{mM}$ sodium pyrophosphate, $1 \mathrm{mM} \beta$-glycerophosphate, $1 \mathrm{mM}$ sodium orthovanadate), and a cocktail of protease inhibitors. The lysate was centrifuged at $1400 \mathrm{~g}$ for $30 \mathrm{~min}$ at $4^{\circ} \mathrm{C}$. Protein levels in lysates were measured according to Lowry et al (1951).

\section{PI 3-Kinase Activity Assay}

P13-K activity was measured essentially by the procedure described by Hsiung et al (2003). Postmortem brain lysates $(600 \mu \mathrm{g}$ protein) were immunoprecipitated with an antibody directed against the p85 subunit and incubated on ice for $60 \mathrm{~min}$. Protein $\mathrm{A} / \mathrm{G}$-agarose $(30 \mu \mathrm{l})$ was then added, and incubation was continued for $60 \mathrm{~min}$ at $4^{\circ} \mathrm{C}$. The lysate was centrifuged and the pellet was washed with $500 \mu \mathrm{l}$ of lysis buffer containing $25 \mathrm{mM}$ HEPES (pH 7.5), $150 \mathrm{mM} \mathrm{NaC1}$, $1 \mathrm{mM}$ EDTA, $1 \mathrm{mM}$ EGTA, $1 \%$ Triton X-100, $1 \mathrm{mM}$ sodium orthovanadate, and a cocktail of protease inhibitors. The pellet was washed again with $500 \mu \mathrm{l}$ kinase buffer $(30 \mathrm{mM}$ HEPES ( $\mathrm{pH} 7.5$ ) and $30 \mathrm{mM} \mathrm{MgCl}_{2}$ ) and suspended in sonicated soybean phosphatidylinositol $(20 \mu \mathrm{g})$ and $35 \mu \mathrm{l}$ kinase assay buffer. The reaction was initiated by the addition of $50 \mu \mathrm{M}$ ATP and $5 \mu \mathrm{Ci}\left[\gamma^{32} \mathrm{P}\right] \mathrm{ATP}(3000 \mathrm{Ci} / \mathrm{mmol})$ in $5 \mu \mathrm{l}$ kinase buffer, incubated for $10 \mathrm{~min}$ at $30^{\circ} \mathrm{C}$, and stopped by the addition of $100 \mu \mathrm{l}$ of $1 \mathrm{~N} \mathrm{HCl}$. Lipids were extracted with $200 \mu \mathrm{l}$ of chloroform: methanol $(1: 1)$, spotted on to silica gel G-60 TLC plates, and developed in a mobile phase consisting of chloroform, acetone, methanol, acetic acid, and water $(40: 15: 13: 12: 7 ; \mathrm{v} / \mathrm{v} / \mathrm{v} / \mathrm{v} / \mathrm{v})$. Spots corresponding to phosphatidylinositol 3-phosphate (PI(3)P) were detected by autoradiography and identified on the basis of their co-migration with a known standard. PI 3-kinase activity was quantified by cutting the spots corresponding to PI3-P from the plate and analyzing them by liquid scintillation counting.

\section{Western Blot of Catalytic and Regulatory Subunits of PI 3-Kinase}

Sample lysates were boiled for $5 \mathrm{~min}$, vortexed, and then centrifuged for $2 \mathrm{~min}$. Equal amounts of samples $(35 \mu \mathrm{g}$ protein) were loaded on a $7 \%(\mathrm{w} / \mathrm{v})$ polyacrylamide gel using the Mini Protein II gel apparatus (Bio-Rad Laboratories, Hercules, CA, USA). The gels were run using $25 \mathrm{mM}$ Tris base, $192 \mathrm{mM}$ glycine, and $0.1 \%(\mathrm{w} / \mathrm{v})$ SDS at $150 \mathrm{~V}$. The proteins were subsequently transferred electrophoretically using $25 \mathrm{mM}$ Tris base, $0.2 \mathrm{M}$ glycine, and $20 \%$ methanol $(\mathrm{pH} 8.5)$ to an enhanced chemiluminescence (ECL) nitrocellulose membrane using the Mini Trans-Blot (BioRad Laboratories) at $0.15 \mathrm{~A}$ constant current. Membranes were washed with TBST ( $10 \mathrm{mM}$ Tris base, $0.15 \mathrm{M} \mathrm{NaCl}$, and $0.05 \%$ Tween 20 ) buffer for $5 \mathrm{~min}$. The blots were blocked by incubating with $5 \%(\mathrm{w} / \mathrm{v})$ powdered nonfat milk in TBST, $0.2 \%(\mathrm{v} / \mathrm{v})$ Nonidet P-40, and $0.02 \%(\mathrm{w} / \mathrm{v})$ SDS ( $\mathrm{pH}$ 8.0) for $1 \mathrm{~h}$ and were incubated overnight at $4{ }^{\circ} \mathrm{C}$ with primary antibody for $\mathrm{p} 85 \alpha(1: 750)$, p $85 \beta(1: 500)$, $\mathrm{p} 110 \alpha$ $(1: 650)$, or p110 $\beta(1: 500)$ obtained from different sources (p85 $\alpha$, BD Pharmingen, San Jose, CA, USA; p85 $\beta$, GeneTex, San Antonio, TX, USA; p110 $\alpha$, Cell Signaling, Beverly, MA, USA; p110 $\beta$, Santa Cruz Biotechnology, Santa Cruz, CA, USA). The membranes were washed three times for $10 \mathrm{~min}$ each with TBST, and then membranes were incubated with HRP-conjugated anti-goat secondary antibody (1:1000 dilution) for $5 \mathrm{~h}$ at room temperature. Membranes were washed three times, $10 \mathrm{~min}$ each, with TBST. The membranes were stripped using stripping buffer (Chemicon International, Temecula, CA, USA) and treated with primary $\beta$-actin antibody $(1.1 \mathrm{mg} / \mathrm{ml} ; 1: 3000$ dilution) for $3 \mathrm{~h}$ and secondary HRP-linked anti-rabbit/mouse antibody (1:5000 dilution) for $2 \mathrm{~h}$. $\beta$-actin was used as a housekeeping protein to reduce interblot variability. Membranes were then incubated with a chemiluminescent detection reagent (New England Bio Labs Inc., Beverly, MA, USA) at room temperature. The membranes were exposed on ECL-autoradiographic films. Before the experiment, the dilution of the antibody and the duration of the exposure of the nitrocellulose membranes on autoradiographic film were standardized. The bands on the autoradiograms were quantified using the Loats Image Analysis System (Westminister, MD, USA), and the optical density (OD) of each sample was corrected by the OD of the corresponding $\beta$-actin band. The values are presented as a percent of the control. 
The specificity of band on the autoradiogram was checked by using a 100 -fold excess of blocking peptide (relative to the molarity of the antiserum) corresponding to the epitope used to generate the PI 3-kinase subunits. We also examined the antibodies by including positive cells (K-562 whole cell lysate; SH-SY5Y; SK-N-SH) along with human PFC and hippocampus for western blot and observed that the bands in PFC and hippocampus were of the same size as observed in cell lines. In addition, to validate our data, we initially determined the immunolabeling in PFC and hippocampus of suicide and control subjects using five different concentrations of protein $(10-80 \mu \mathrm{g})$. The OD of the band increased linearly with increased concentration of protein (data not shown).

\section{Determination of mRNA Levels of Catalytic and Regulatory Subunits of PI 3-Kinase}

The procedures for RNA isolation and competitive RT-PCR analysis have been extensively used by us (Dwivedi et al, 2002, 2003a, b, 2006). Brain tissues were homogenized in $4 \mathrm{M}$ guanidine isothiocyanate, $50 \mathrm{mM}$ Tris $/ \mathrm{HCl}(\mathrm{pH}=7.4)$, and $25 \mathrm{mM}$ EDTA, and the total RNA was isolated by $\mathrm{CsCl}_{2}$ ultracentrifugation. The yield of total RNA was determined by measuring the absorbency of an aliquot of the precipitated stock at a wavelength of $260 / 280 \mathrm{~nm}$. Samples with a ratio below 1.8 were rejected. The quality of total RNA was determined by visual assessment of the $28 \mathrm{~S}: 18 \mathrm{~S}$ rRNA ratio on a denaturing agarose gel. In addition, to determine the integrity of RNA, all samples were analyzed using the Bioanalyzer 2100 (Agilent Technology, Palo Alto, CA, USA) according to the manufacturer's instructions. The
RNA was diluted to a concentration of $100 \mathrm{ng} / \mu \mathrm{l}$, and a $1 \mu \mathrm{l}$ aliquot was analyzed using the lab-on-a-chip technology of the Agilent Bioanalyzer. Only samples with an RNA integrity number $>6$ were used in this study.

The mRNA levels of the various catalytic and regulatory subunits of PI 3-kinase were quantitated using internal standards. We also determined mRNA levels of cyclophilin and neuron-specific enolase (NSE), which were used as housekeeping genes. Cloning and synthesis of internal standards have been described in our earlier publications (Dwivedi et al, 2002, 2006). The sequences of external and internal primers for catalytic and regulatory subunits of PI 3-kinase, cyclophilin, and NSE are given in Table 1. The single-strand internal standards were designed and synthesized identical to the target gene mRNA, with a specific deletion mutation introduced between the PCR primers. This was done to allow differentiation between the target gene mRNA and the internal standard by gel electrophoresis. Each of the internal standards was synthesized in two PCR steps, starting with a cDNA template reverse transcribed from the total RNA. The internal standard templates were first cloned into a pGEM4Z vector, using M13 primers, and then transcribed using SP6 RNA polymerase. For NSE, internal standard was generated by site-directed mutagenesis to introduce an Xho I restriction site between the amplification primers so that the digestion of the amplicon would generate two fragments of approximately equal molecular size. To make sure that amplified sequences of PI 3-kinase catalytic and regulatory subunit isoforms and of cyclophilin and NSE match with the corresponding sequences reported in GenBank, the internal standards were sequenced using M13 primer.

Table I External and Internal Primer Sequences

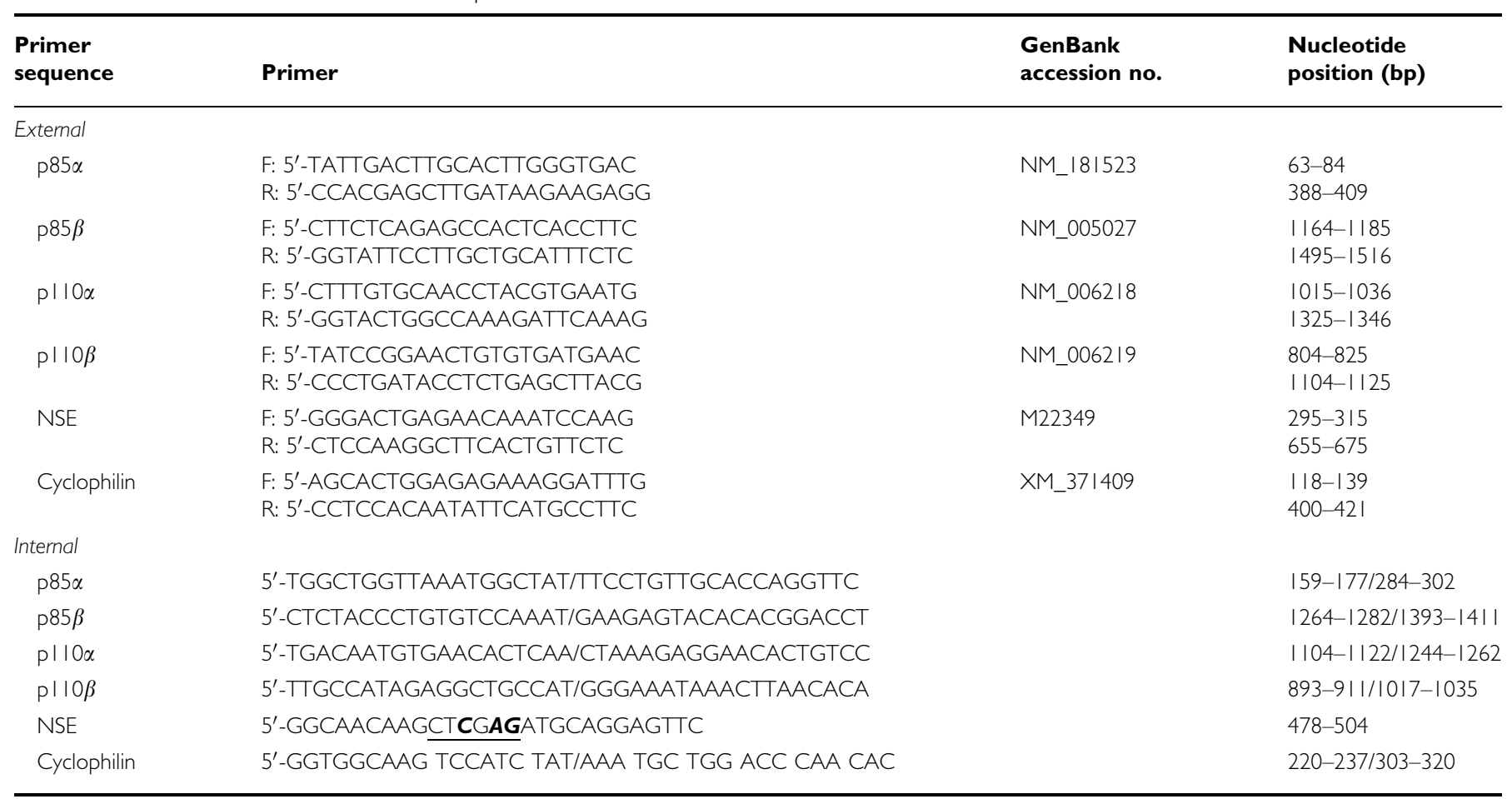

Abbreviations: F, forward; $R$, reverse.

Bold and italics letters show mutation sites and underlined bases show restriction enzyme (Xhol) site. 


\section{PI 3-kinase signaling and suicide}

Y Dwivedi et al

Table 2 Characteristics of Suicide and Control Subjects

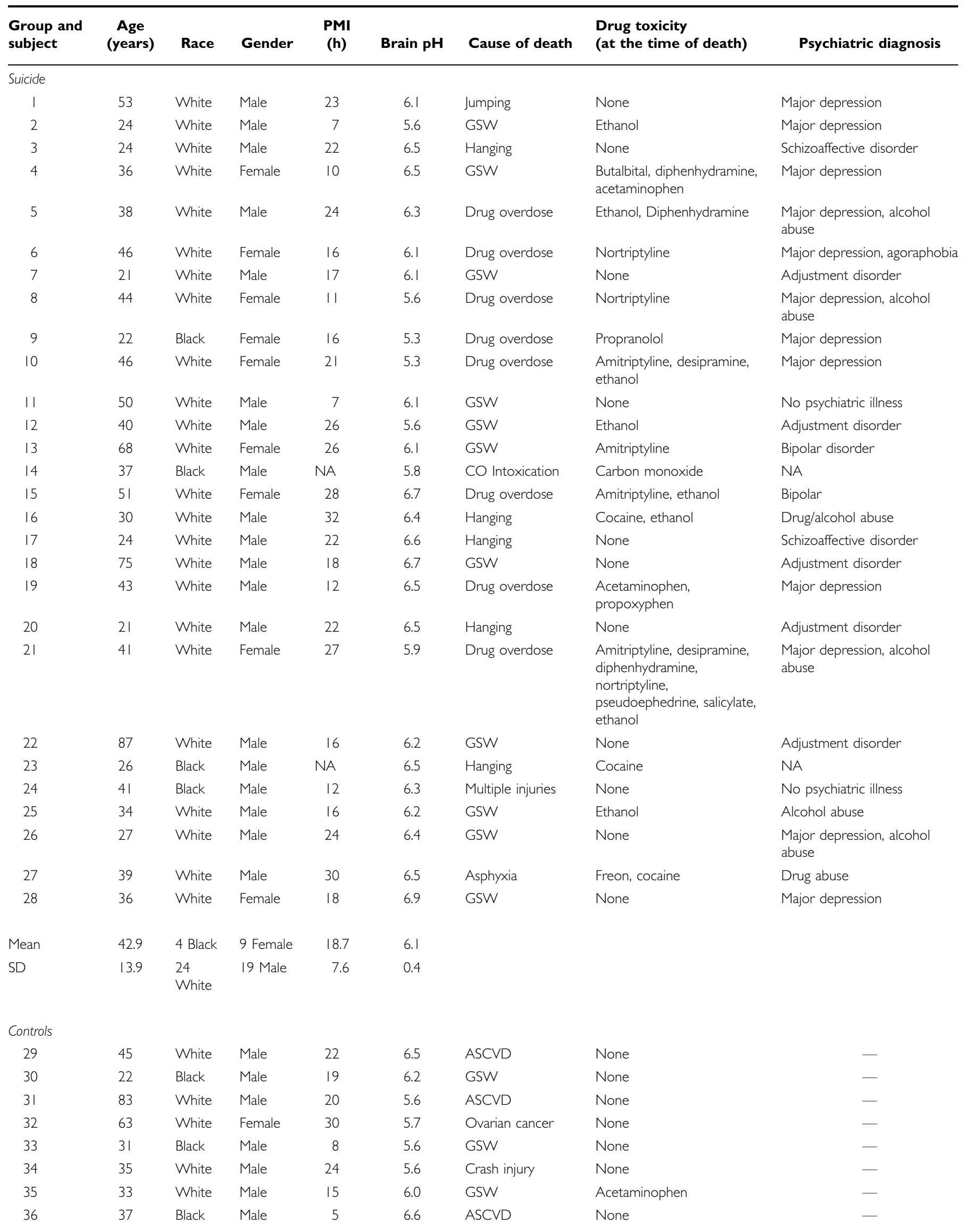


Table 2 Continued

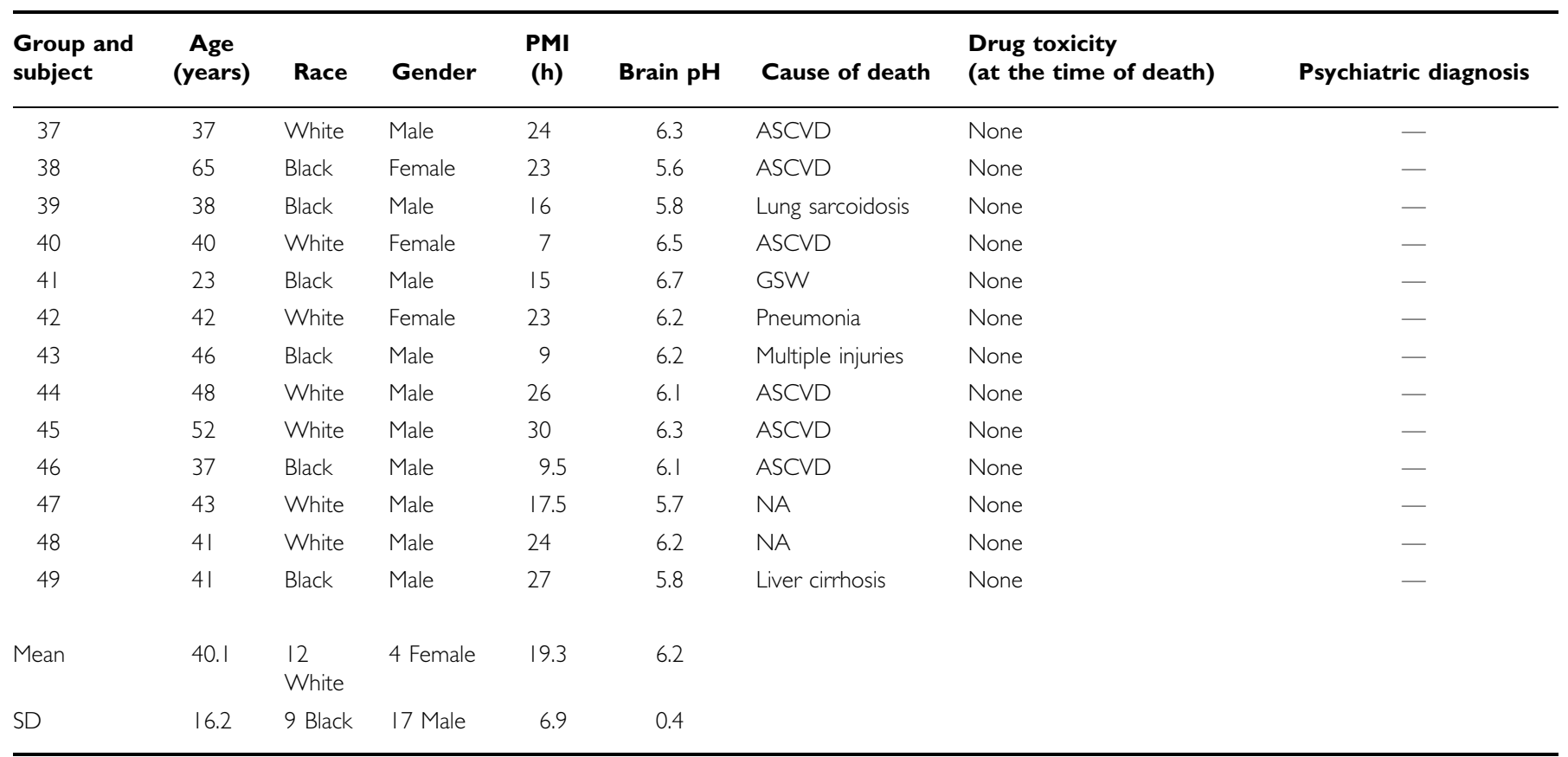

Abbreviations: ASCVD, atherosclerotic cardiovascular disease; GSW, gunshot wound; NA, not available.

Quantitative analyses of catalytic and regulatory subunits of PI 3-kinase were performed by competitive RT-PCR as described earlier (Dwivedi et al, 2002). A constant amount of total RNA and five decreasing amounts of internal standard (a twofold dilution series) were used to determine the amount of target RNA present in each sample. Decreasing concentrations of p $85 \alpha(50-3.125 \mathrm{pg})$, p85 $\beta$ (400-25 pg), p110 $\alpha$ (200-12.5 pg), p110 $\beta$ (25000$1562.5 \mathrm{pg}$ ), cyclophilin (200-12.5 pg), or NSE (100-3.125 pg) internal standard cRNAs were added to $1 \mu \mathrm{g}$ of total RNA. The PCR mixture was amplified for 30 cycles. Following amplification, aliquots were run on a $1.5 \%$ agarose gel.

To quantitate the amount of product corresponding to the reverse-transcribed and amplified mRNA, the ethidium bromide-stained bands were excised and counted. The results were calculated as the counts incorporated into the amplified cRNA standard divided by the counts incorporated into the corresponding mRNA amplification product vs a known amount of internal standard cRNA added to the test sample. The results are expressed as attomoles mRNA per microgram of total RNA.

\section{Statistical Analysis}

Data analyses were performed using the SPSS version 15 (Chicago, IL, USA). Data are reported as the mean \pm SD. All the dependent variables were first subjected to tests of normality. The assumption of normality was tested using the Shapiro-Wilk test. Both normal controls and suicide groups were tested for normality separately. To adjust for multiplicity of testing based on multiple endpoints (ie dependent variables), a multiple analysis of covariance (MANCOVA) was applied to the data for each brain area (ie PFC, hippocampus, and cerebellum). Age, gender, $\mathrm{pH}$ of the brain, race, and postmortem interval (PMI) were used as covariates. The assumption of homogeneity of variance was tested using Box's test of equality of covariance matrices. In the presence of a significant MANCOVA for a given brain area, ANCOVAs were performed for each dependent variable. If a MANCOVA was not significant, no further analysis was performed for that brain area. For the two-group analysis (normal controls vs suicide subjects) MANCOVA was followed by ANCOVA. For the three-group analysis (normal controls, depressed suicide subjects, suicide subjects with other psychiatric disorders), if the ANCOVA for that dependent variable was significant, pariwise between-group comparisons were performed for each dependant variable.

The differences in age, gender, $\mathrm{pH}$ of the brain, and PMI, between suicide subjects and normal controls were analyzed using the independent-sample ' $t$ ' test. In addition, relationships between the mRNA and protein levels, as well as the catalytic activity of PI 3-kinase, and PMI, age, and $\mathrm{pH}$ of the brain were also determined using Pearson product-moment correlation analysis. The effects of gender on various measures were also determined by an independent sample ' $t$ ' test comparing males and females. Similarly, an independent sample ' $t$ ' test was used to compare the depressed subjects who showed presence of antidepressant at the time of death with the depressed subjects who did not.

\section{RESULTS}

The demographic characteristics of suicide subjects and normal control subjects are provided in Table 2. There were 17 males and 4 females in the control group, and 19 males and 9 females in the suicide group. The age range was 21-87 years; the PMI range was 5-32 h. There were no significant 
differences in age $(t=0.63, \mathrm{df}=47, P=0.53)$ or PMI $(t=0.29, \mathrm{df}=45, P=0.77)$ between suicide subjects and normal control subjects. The mean brain $\mathrm{pH}$ values of suicide subjects and normal controls were $6.1 \pm 0.1$ and $6.2 \pm 0.4$, respectively, which were not statistically different between these groups $(t=1.00, \mathrm{df}=47, P=0.32)$.

\section{Overall Analysis of Data}

We measured PI 3-kinase activity, mRNA and protein levels of $\mathrm{p} 110 \alpha, \mathrm{p} 110 \beta, \mathrm{p} 85 \alpha$, and $\mathrm{p} 85 \beta$ in PFC and hippocampus (a total of nine dependant variables), and PI 3-kinase activity and protein levels of $\mathrm{p} 110 \alpha, \mathrm{p} 110 \beta, \mathrm{p} 85 \alpha$, and $\mathrm{p} 85 \beta$ (a total of five dependent variables) in cerebellum brain areas. All dependent variables in the three brain areas were first subjected to tests of normality using the Shapiro-Wilk test. We found nonsignificant $P$ values $(>0.05)$ for tests of normality for all dependent variables in PFC, hippocampus, and cerebellum of both normal control and suicide groups, indicating that we cannot reject the null hypothesis that the data are normally distributed. We used Box's test of equality of covariance matrices to test the assumption of betweengroup equality. No significant between-group differences were found for covariance matrices in the PFC $(P=1.01)$, hippocampus $(P=0.08)$, or cerebellum $(P=0.94)$. The overall MANCOVA for all nine dependent variables adjusted for covariates was significant for the PFC $(\mathrm{F}=11.95, \quad \mathrm{df}=9, \quad 32, \quad P<0.001) \quad$ and hippocampus $(\mathrm{F}=17.10, \mathrm{df}=9,27, P<0.001)$, but was not significant for the cerebellum $(\mathrm{F}=2.4, \mathrm{df}=5,36, P=0.07)$, when the normal control group was compared with the suicide group. In the following sections, we describe the results of the individual ANCOVAs for each dependent variable for the PFC and hippocampus.

\section{PI 3-Kinase Activity}

PI 3-kinase activity was determined in lysates prepared from PFC, hippocampus, or cerebellum. Representative autoradiograms showing PI 3-kinase activity in PFC, hippocampus, and cerebellum of two normal controls and two suicide subjects are shown in Figure 1a, and mean values are presented as bar diagrams in Figure $1 \mathrm{~b}$. We observed that relative catalytic activity in normal control subjects was almost the same in these three brain areas. The catalytic activity of PI 3-kinase was significantly decreased in PFC $(t=4.41, \mathrm{df}=47, P<0.001)$ and hippocampus $(t=4.26, \mathrm{df}=40, P<0.001)$ of suicide subjects compared with normal controls (Figure $1 b$ ).

\section{Western Blot of PI3-Kinase Regulatory and Catalytic Subunits}

Immunolabeling of regulatory $\mathrm{p} 85 \alpha$ and $\mathrm{p} 85 \beta$ and of catalytic $\mathrm{p} 110 \alpha$ and $\mathrm{p} 110 \beta$ was examined in the same lysates in which catalytic activity was determined, and representative western blots are depicted in Figure 2. We observed that $\mathrm{p} 85 \alpha$ and $\mathrm{p} 85 \beta$ migrated to 85 and $82 \mathrm{kDa}$, respectively, whereas $\mathrm{p} 110 \alpha$ and $\mathrm{p} 110 \beta$ migrated to $110 \mathrm{kDa}$. $\beta$-Actin migrated to $46 \mathrm{kDa}$. OD ratios of regulatory or catalytic subunits with $\beta$-actin were calculated and represented as percent of control.
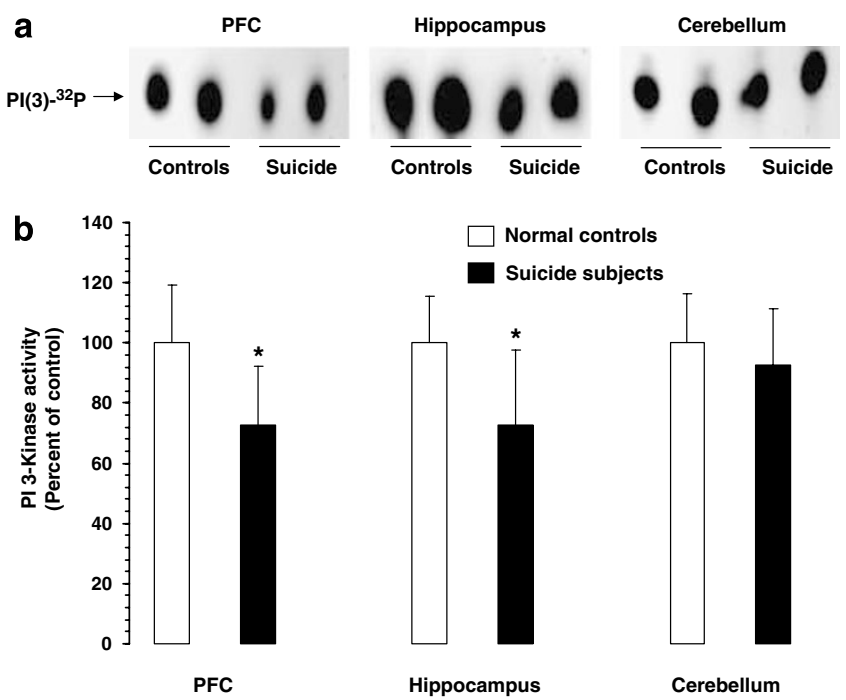

Figure I Catalytic activity of PI 3-kinase in PFC, hippocampus, and cerebellum of suicide subjects and normal controls. (a) Representative autoradiograms showing PI 3-kinase activity in PFC, hippocampus, and cerebellum determined after immunoprecipitation using p85 antibody. The reaction was initiated by the addition of $50 \mu \mathrm{M}$ ATP and $5 \mu \mathrm{Ci}\left[\gamma^{32} \mathrm{P}\right] \mathrm{ATP}$ $\left(3000 \mathrm{Ci} / \mathrm{mmol}\right.$ ) in $5 \mu \mathrm{l}$ kinase buffer, incubated for $10 \mathrm{~min}$ at $30^{\circ} \mathrm{C}$, and stopped by the addition of $100 \mu|| \mathrm{N} \mathrm{HCl}$. Lipids were extracted with $200 \mu \mathrm{l}$ of chloroform:methanol $(\mathrm{I}: \mathrm{I})$, spotted on to silica gel G-60 TLC plates, and developed in a mobile phase consisting of chloroform, acetone, methanol, acetic acid, and water (40: I5: 13:12:7; v/v/v/v/v). (b) Mean $\pm S D$ of $\mathrm{Pl} 3$-kinase activity in PFC, hippocampus, and cerebellum of suicide subjects and normal controls. PFC samples were from 21 normal controls and 28 suicide subjects; hippocampus and cerebellum samples were from 21 normal controls and 21 suicide subjects. $* P=0.001$

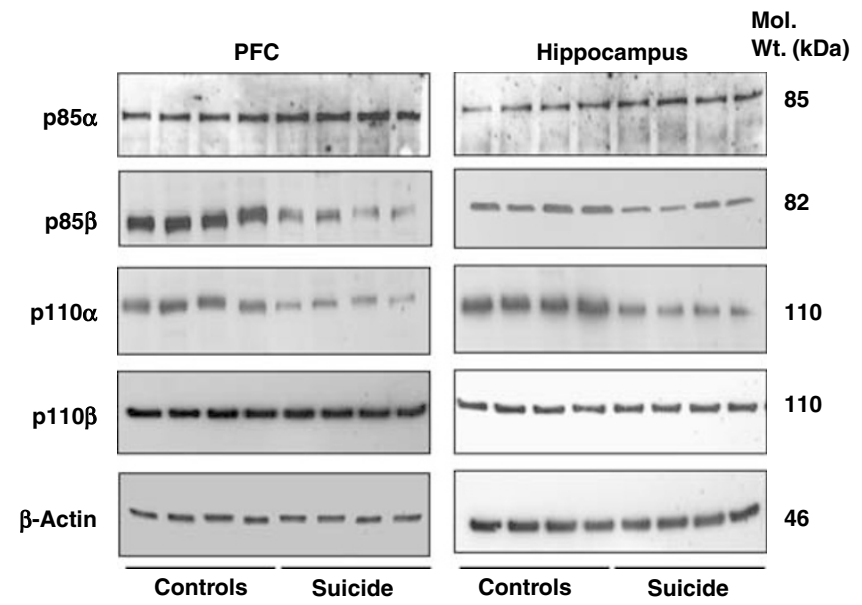

Figure 2 Representative western blots showing the immunolabeling of $\mathrm{p} 85 \alpha, \mathrm{p} 85 \beta, \mathrm{p}|| 0 \alpha, \mathrm{p} \mid \mathrm{I0} \beta$, and $\beta$-actin in lysate of PFC and hippocampus of four normal controls and four suicide subjects. Protein samples were subjected to $7 \%$ polyacrylamide gel electrophoresis and transferred to ECL-nitrocellulose membranes, which were then incubated with primary antibody specific for $\mathrm{p} 85 \alpha, \mathrm{p} 85 \beta, \mathrm{pl|O \alpha}, \mathrm{p} \mid \mathrm{IO} \beta$, or $\beta$-actin and corresponding secondary antibody. The bands were quantified as described in the 'Materials and methods' section. Ratios of the optical density of $\mathrm{p} 85 \alpha$, $\mathrm{p} 85 \beta$, $\mathrm{pl} \mid \mathrm{O} \alpha$, or $\mathrm{p} \mid \mathrm{IO} \beta$ to that of $\beta$-actin were calculated and reported as percent of control. 

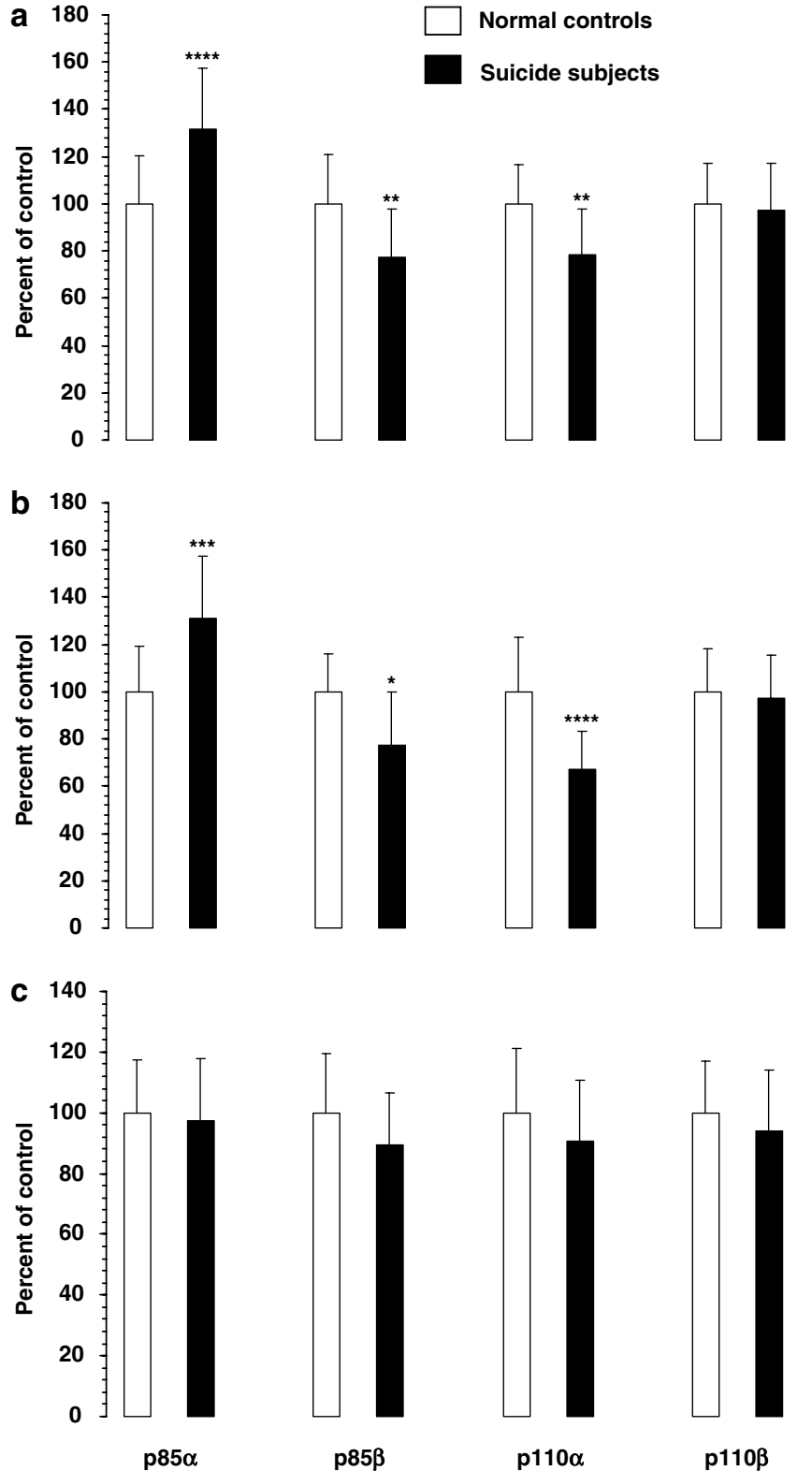

Figure 3 The mean $\pm \mathrm{SD}$ of immunolabeling of $\mathrm{p} 85 \alpha, \mathrm{p} 85 \beta, \mathrm{p} \mid \mathrm{IO} \alpha$, or pIIO $\beta$ in PFC (a), hippocampus (b), and cerebellum (c) from normal controls and suicide subjects. PFC samples were from 21 normal controls and 28 suicide subjects; hippocampus and cerebellum samples were from 21 normal controls and 21 suicide subjects. Suicide group was compared with control group. $* P=0.003$, $* * P=0.002$, $* * * P=0.001$, ****** $P<0.001$.

Comparison of regulatory p85 subunits between normal controls and suicide subjects. As shown in Figures 2 and 3, we observed that protein level of p85 $\alpha$ was significantly increased in PFC $(\mathrm{df}=1,40$, $\mathrm{F}=17.67, \quad P<0.001)$ and hippocampus $(\mathrm{df}=1, \quad 35$, $\mathrm{F}=12.15, \quad P=0.001) \quad$ of suicide subjects compared with normal controls. However, the level of $\mathrm{p} 85 \beta$ was significantly decreased in these two brain areas of suicide subjects ( $\mathrm{PFC}: \mathrm{df}=1,40, \mathrm{~F}=10.51, P=0.002$; hippocampus: $\mathrm{df}=1,35, \mathrm{~F}=9.88, P=0.003)$.
Comparison of catalytic p110 subunits between normal controls and suicide subjects. When protein levels of catalytic subunits of PI 3-kinase were compared between normal controls and suicide subjects, it was observed that protein level of p110 $\alpha$ was decreased in both PFC $(\mathrm{df}=1,40$, $\mathrm{F}=11.20, P=0.002)$ and hippocampus $(\mathrm{df}=1,35, \mathrm{~F}=18.33$, $P<0.001$ ), whereas no significant change was observed in protein level of $\mathrm{p} 110 \beta$ ( $\mathrm{PFC}$ : $\mathrm{df}=1,40, \mathrm{~F}=0.72, P=0.40$; hippocampus: $\mathrm{df}=1,35, \mathrm{~F}=0.05, P=0.82$ ).

\section{mRNA Levels of PI3-Kinase Regulatory and Catalytic Subunits}

Since we observed changes in protein levels of $\mathrm{p} 85 \alpha$ and p $85 \beta$ and $\mathrm{p} 110 \alpha$ in PFC and hippocampus, we determined their mRNA levels by quantitative RT-PCR using internal standards in these two brain areas. We also examined the expression level of p110 $\beta$. mRNA levels of cyclophilin and NSE were determined as housekeeping genes. Ratios of mRNA levels of catalytic and regulatory subunits of PI 3-kinase $v s$ cyclophilin or NSE mRNA were calculated. Representative gel electrophoreses showing the competitive RT-PCR for $\mathrm{p} 85 \alpha, \mathrm{p} 85 \beta, \mathrm{p} 110 \alpha$, and $\mathrm{p} 110 \beta$ in total RNA isolated from PFC of one normal control subject are given in Figure 4a, c, e, and g, respectively, whereas competitive PCR analyses are given in Figure $4 \mathrm{~b}, \mathrm{~d}, \mathrm{f}$, and $\mathrm{h}$, respectively. It was observed that the amplification products for $\mathrm{p} 85 \alpha$, $\mathrm{p} 85 \beta, \mathrm{p} 110 \alpha$, and $\mathrm{p} 110 \beta$ arise from the mRNA template at $347,353,332$, and $322 \mathrm{bp}$, respectively. The digestion products from $\mathrm{p} 85 \alpha, \mathrm{p} 85 \beta, \mathrm{p} 110 \alpha$, and $\mathrm{p} 110 \beta$ arise from cRNA at $241,243,211$, and $217 \mathrm{bp}$, respectively.

Relative mRNA expression levels of PI3-kinase regulatory and catalytic subunits in PFC and hippocampus in normal controls. As shown in Figure 5, we observed that the expression level of $\mathrm{p} 85 \alpha$ was similar in hippocampus and PFC. On the other hand, the expression of $\mathrm{p} 85 \beta$ was greater in PFC than hippocampus. However, the expression levels of $\mathrm{p} 85 \beta$ were about 5-10 times greater in PFC and hippocampus than of $\mathrm{p} 85 \alpha$. When comparing the distributions of p110 $\alpha$ and $\mathrm{p} 110 \beta$, we observed that the expression level of p110 $\alpha$ was almost the same in PFC and hippocampus, whereas expression of $\mathrm{p} 110 \beta$ was almost five times greater in PFC than hippocampus. Comparison of $\mathrm{p} 110 \alpha$ and $\mathrm{p} 110 \beta$ isoforms in PFC and hippocampus showed that the level of $110 \beta$ was about 80-100 times greater than the expression of $\mathrm{p} 110 \alpha$ in PFC, whereas in hippocampus the level of $110 \beta$ was about 20-30 times greater than the expression of p110 $\alpha$.

Comparison of $m R N A$ levels of PI3-kinase regulatory and catalytic subunits between normal controls and suicide subjects. ANCOVA showed that the mRNA level of p85 $\alpha$ was significantly increased in $\mathrm{PFC}(\mathrm{df}=1,40, \mathrm{~F}=9.93, P=$ $0.003)$ and hippocampus $(\mathrm{df}=1,35, \mathrm{~F}=16.08, P<0.001)$, whereas the mRNA level of $\mathrm{p} 85 \beta$ was significantly decreased in PFC $(\mathrm{df}=1,40, \mathrm{~F}=32.85, P<0.001)$ and hippocampus $(\mathrm{df}=1,35, \mathrm{~F}=15.73, P<0.001)$ of suicide subjects compared with normal control subjects (Figure 5). On the other hand, the mRNA level of $\mathrm{p} 110 \alpha$ was significantly decreased in PFC $(\mathrm{df}=1,40, \mathrm{~F}=6.30, P=0.016)$ and hippocampus $(\mathrm{df}=1,35, \mathrm{~F}=17.32, P<0.001)$ of suicide subjects. No significant change was noted in mRNA level of $\mathrm{p} 110 \beta$, either 


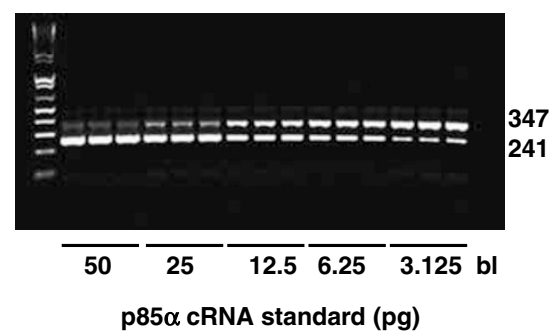

b

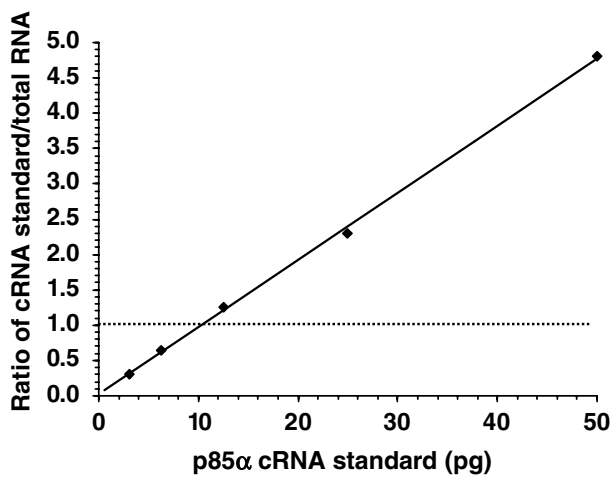

e

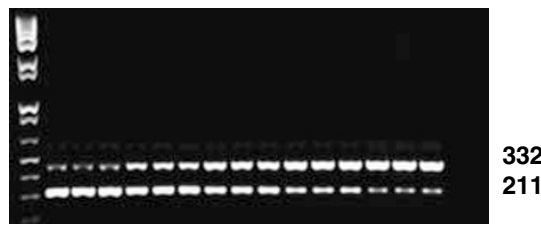

$200 \overline{100} \overline{50} \overline{25} \overline{12.5}$ bl

p110 $\alpha$ cRNA standard (pg)

f

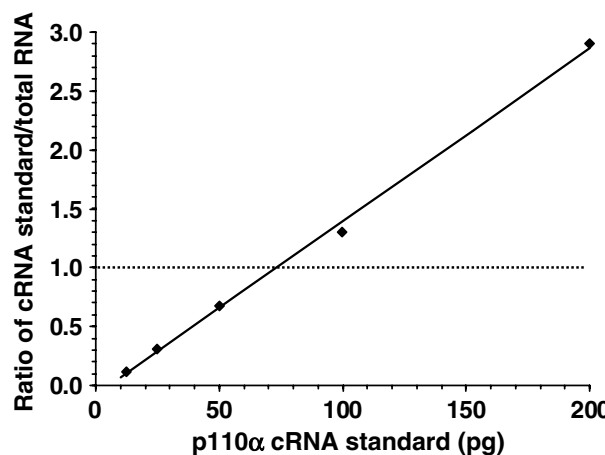

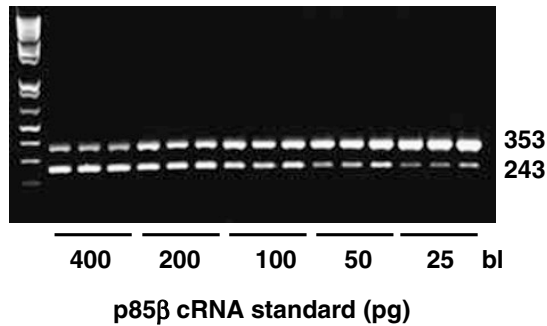

d

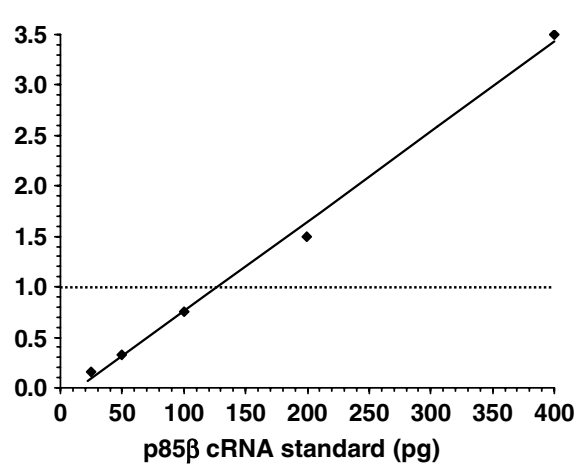

g

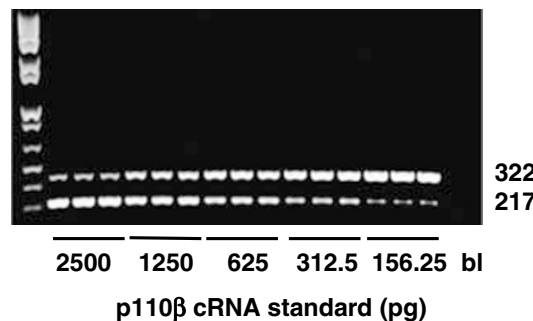

h 3.

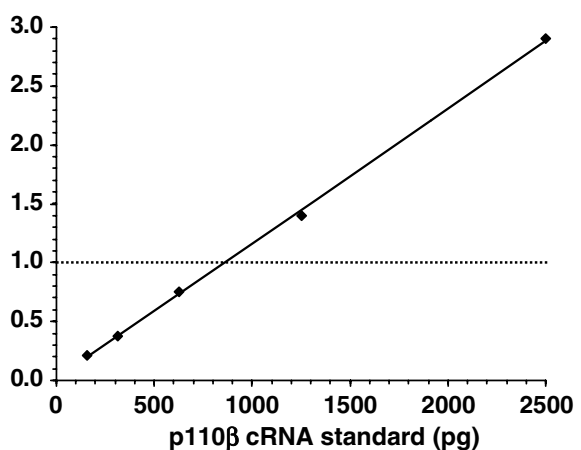

Figure 4 Representative gel electrophoreses showing competitive PCR analysis for $\mathrm{p} 85 \alpha(\mathrm{a}), \mathrm{p} 85 \beta$ (c), $\mathrm{p} \mid \mathrm{IO} \alpha$ (e), or $\mathrm{p} \mid \mathrm{IO} \beta$ (g) mRNA contents in PFC obtained from one normal control subject. Decreasing concentrations of internal standard cRNA (p85 $\alpha, 50-3.125$ pg; p85 $\beta$, 400-25 pg; I I 0 $\alpha, 200-12.5$ pg) were added to a constant amount (I $\mu \mathrm{g}$ ) of total RNA, except for I IO $\beta$, for which 2500-156.25 pg internal standard was added to $0.1 \mu \mathrm{g}$ total RNA. The mixtures were reverse transcribed and PCR-amplified in the presence of trace amounts of [ $\left.{ }^{32} \mathrm{P}\right] \mathrm{dCTP}$; aliquots were electrophoresed on $1.5 \%$ agarose gel. The higher molecular size band corresponds to the amplification product arising from the mRNA, whereas the lower bands arise from cRNA generated from the internal standard; bl represents blank. Data derived from the agarose gel are plotted as the counts incorporated into the amplified $p 85 \alpha$ (b), $p 85 \beta$ (d), $\mathrm{pl} \mathrm{IO \alpha} \mathrm{(f),} \mathrm{or} \mathrm{p} \mathrm{I} \mathrm{IO} \beta(\mathrm{h})$ cRNA standard divided by the counts incorporated into the corresponding mRNA amplification product vs the known amount of internal standard cRNA added to the test sample. The point of equivalence represents the amount of the respective mRNA.

in PFC $(\mathrm{df}=1,40, \mathrm{~F}=0.06, P=0.81)$ or hippocampus $(\mathrm{df}=1,35, \mathrm{~F}=0.99, P=0.33)$ of suicide subjects (Figure 5$)$.

Comparison of mRNA levels of cyclophilin and NSE and of ratios of $m R N A$ levels of PI3-kinase regulatory and catalytic subunits to cyclophilin and NSE between normal controls and suicide subjects. We used cyclophilin and NSE as housekeeping genes. We did not find a significant difference in mRNA levels of cyclophilin between normal controls and suicide subjects, either in PFC (controls: $776.66 \pm 112.5$, suicide: $801.53 \pm 117.34$ attomol $/ \mu \mathrm{g}$ total RNA) or in hippocampus (controls: $783.47 \pm 110.12$, suicide: $768.34 \pm 102.76$ attomol $/ \mu \mathrm{g}$ total RNA). Similarly, no significant difference was observed in mRNA levels of NSE in PFC (controls: $360.23 \pm 47.68$, suicide: $344.04 \pm$ $43.97 \mathrm{attomol} / \mu \mathrm{g}$ total RNA) or hippocampus (controls: $349.80 \pm 38.15$, suicide: $345.91 \pm 81.36 \mathrm{attomol} / \mu \mathrm{g}$ total RNA) between normal controls and suicide subjects. 

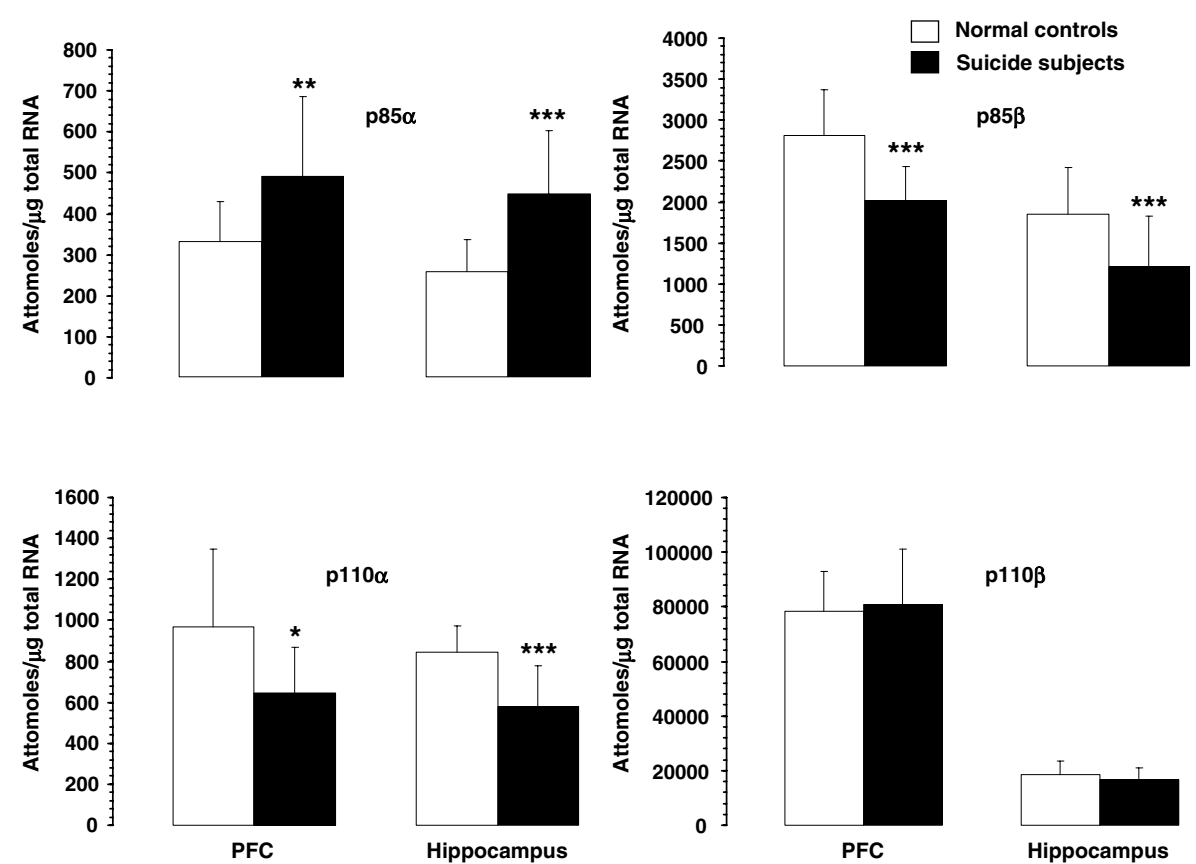

Figure 5 mRNA levels of various catalytic and regulatory subunits of PI 3-kinase in PFC and hippocampus of suicide subjects and normal controls. Data are the mean \pm SD PFC samples were from 21 normal controls and 28 suicide subjects; hippocampus samples were from 21 normal controls and 21 suicide subjects. $* P=0.01, * * *=0.003, * * * P<0.001$.
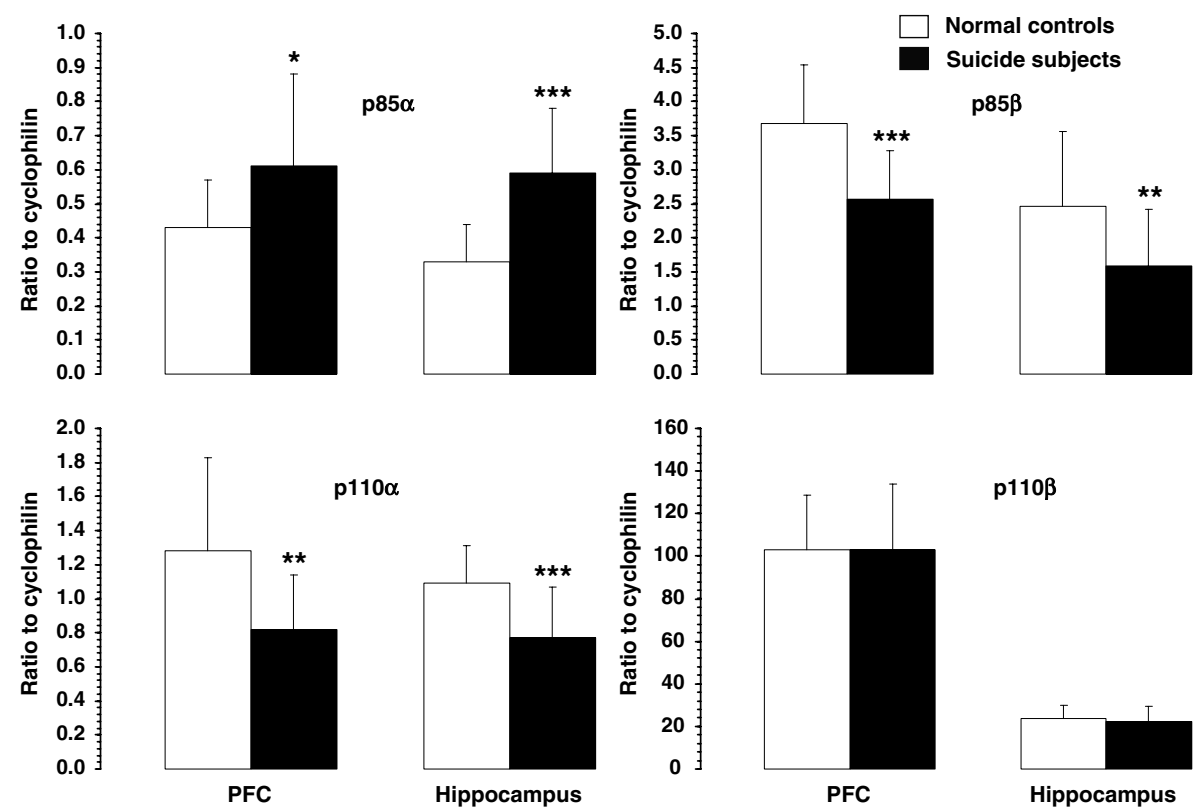

p110

Figure 6 mRNA levels of various catalytic and regulatory subunits of PI 3-kinase shown as a ratio to cyclophilin in PFC and hippocampus of suicide subjects and normal controls. Data are the mean \pm SD PFC samples were from 21 normal controls and 28 suicide subjects; hippocampus samples were from 21 normal controls and 21 suicide subjects. $* P<0.008$, $* * P=0.001$, $* * * * P<0.001$.

The ratios of $\mathrm{p} 85 \alpha, \mathrm{p} 85 \beta, \mathrm{p} 110 \alpha$, or $\mathrm{p} 110 \beta$ vs cyclophilin or NSE mRNAs in PFC and hippocampus are given in Figures 6 and 7, respectively. It was observed that the mRNA level of $\mathrm{p} 85 \alpha$ was significantly increased (PFC: $P=0.008$; hippocampus: $P<0.001)$ and that levels of $\mathrm{p} 85 \beta$ (PFC: $P<0.001$; hippocampus: $P=0.007$ ) and $\mathrm{p} 110 \alpha$ $(P=0.001$; hippocampus: $P<0.001)$ were significantly decreased in PFC and hippocampus of suicide subjects also when expressed as a ratio to cyclophilin mRNA (Figure 6). Similarly too, when mRNA ratios of NSE to catalytic or regulatory subunits of PI 3-kinase were calculated, the level of p85 $\alpha$ was significantly increased in PFC $(P=0.001)$ and hippocampus $(P<0.001)$, and levels of $\mathrm{p} 85 \beta$ and $\mathrm{p} 110 \alpha$ were significantly decreased in PFC (p85 $\beta: P<0.001 ; \mathrm{p} 110 \alpha$ : $P<0.001$ ) and hippocampus (p85 $\beta: P=0.03 ; \mathrm{p} 110 \alpha: P=$ 0.002 ) (Figure 7). In addition, no significant changes were 

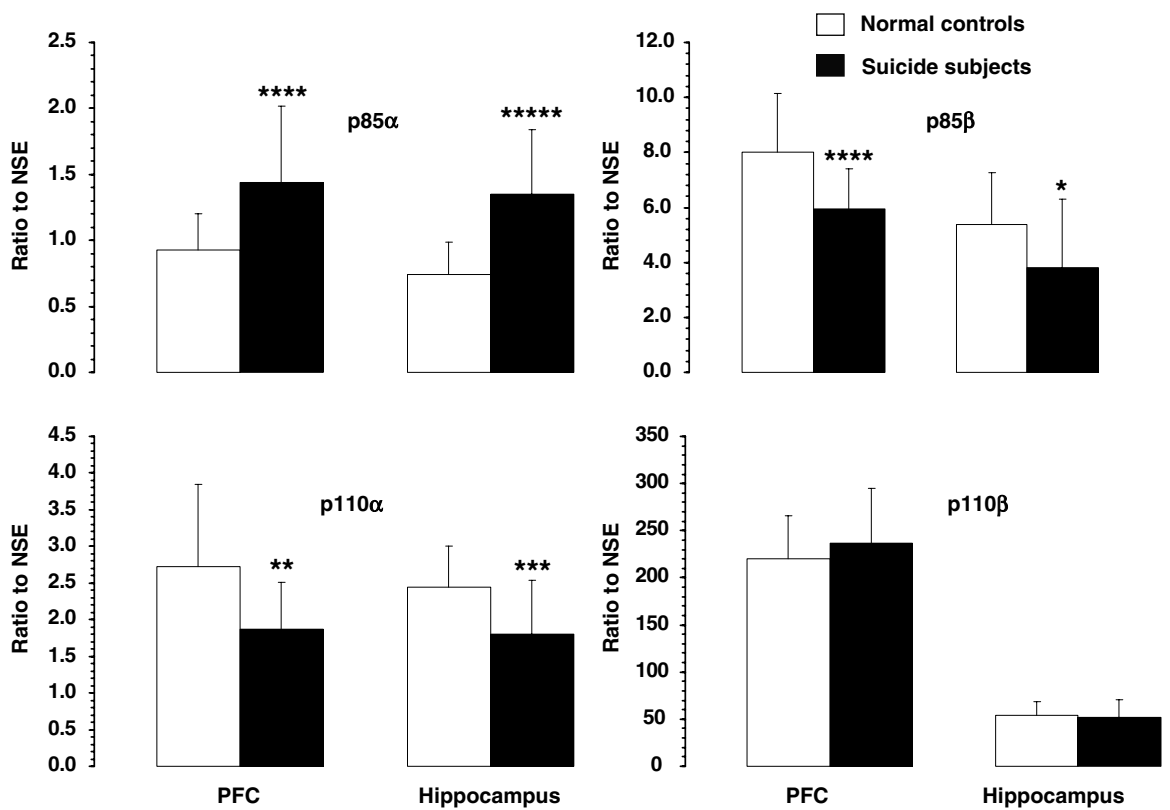

Figure 7 mRNA levels of various catalytic and regulatory subunits of PI 3-kinase shown as a ratio to NSE in PFC and hippocampus of suicide subjects and normal controls. Data are the mean \pm SD PFC samples were from 21 normal controls and 28 suicide subjects; hippocampus samples were from 21 normal controls and 21 suicide subjects. $* P<0.03$, $* * P=0.004$, $* * * P=0.002$, ***** $P=0.00$ I, $* * * * * * P<0.00$ I.

noted in p110 $\beta$ mRNA either in PFC or in hippocampus when expressed as a ratio to cyclophilin (PFC: $P=0.99$; hippocampus: $P=0.47$ ) or to NSE (PFC: $P=0.27$; hippocampus: $P=0.80)$ mRNA.

\section{Effects of Confounding Variables}

The effects of potential confounding variables, namely, age, gender, PMI, brain $\mathrm{pH}$, antidepressant treatment, presence of alcohol, and method of suicide, were evaluated with respect to PI 3-kinase activity and mRNA and protein levels of PI 3-kinase regulatory and catalytic subunits.

Effects of age, PMI, gender, $p H$ of the brain, and methods of suicide. We found no significant effects of age on PI 3-kinase activity (PFC: $r=0.09, P=0.52$; hippocampus: 0.17 , $P=0.27)$. Similarly, age had no significant effect on protein levels of $\mathrm{p} 85 \beta$ or $\mathrm{p} 110 \alpha$, either in PFC (p85 $\alpha, r=0.13$, $P=0.37 ; \mathrm{p} 85 \beta, r=0.08, P=0.60 ; \mathrm{p} 110 \alpha, r=0.01, P=0.91)$ or in hippocampus (p85 $\beta, r=0.08, P=0.61 ; \mathrm{p} 110 \alpha, r=0.18$, $P=0.25$ ). Moreover, no significant effect of age was observed on mRNA levels of $\mathrm{p} 85 \beta$ or p $110 \alpha$ either in PFC (p85 $\beta, r=0.15, P=0.52 ; \mathrm{p} 110 \alpha, r=0.07, P=0.63$ ) or in hippocampus (p85 $\beta, r=0.15, P=0.35 ; \mathrm{p} 110 \alpha, r=0.06$, $P=0.68)$. However, a significant negative correlation between age and p85 $\alpha$ mRNA in PFC $(r=-0.29, P=0.04)$ but not in hippocampus $(r=0.19, P=0.23)$ was observed.

The PMI also did not have any effect on the mRNA of the indicated catalytic and regulatory subunits (PFC: p85 $\alpha$, $r=0.08, P=0.59$; $110 \alpha, r=0.03, P=0.82$; hippocampus: $\mathrm{p} 85 \alpha, r=0.01, P=0.93$; p $110 \alpha, r=0.04, P=0.81)$ or on their protein levels (PFC: p85 $\alpha, r=0.12, P=0.40$; $855, r=0.07$, $P=0.66 ; \mathrm{p} 110 \alpha, r=0.09, P=0.55$; hippocampus: $\mathrm{p} 85 \alpha$, $r=0.09, P=0.56 ; \mathrm{p} 85 \beta, r=0.02, P=0.88 ; \mathrm{p} 110 \alpha, r=0.001$, $P=0.99$ ), except for a negative correlation of p85 $\beta$ mRNA in hippocampus $(r=-0.49, P=0.001)$ but not in PFC $(r=0.19, P=0.41)$. PI 3-kinase activity was also not affected by PMI (PFC: $r=0.05, P=0.72$, hippocampus: $r=0.03$, $P=0.83)$.

There were 17 males and 4 females in the control group. Comparison studies showed no significant differences in PI 3-kinase activity between males and females in PFC $(t=0.23, \quad \mathrm{df}=19, \quad P=0.82) \quad$ or hippocampus $(t=0.42$, $\mathrm{df}=19, P=0.68)$. Similarly, no significant differences were noted in mRNA levels of p85 $\alpha$ (PFC: $t=1.03, \mathrm{df}=19$, $P=0.32$; hippocampus: $t=0.05, \mathrm{df}=19, P=0.96), \mathrm{p} 85 \beta$ (PFC: $t=1.01, \mathrm{df}=19, P=0.32$; hippocampus: $t=0.14$, $\mathrm{df}=19, P=0.89$ ), or p110 $($ PFC: $t=0.53, \mathrm{df}=19, P=0.59$; hippocampus: $t=0.93, \mathrm{df}=19, P=0.36)$ between males and females. Protein levels of p85 $\alpha$ (PFC: $t=0.19, \mathrm{df}=19$, $P=0.85$; hippocampus: $t=1.63, \mathrm{df}=19, P=0.12), \mathrm{p} 85 \beta$ (PFC: $t=0.13, \mathrm{df}=19, P=0.89$; hippocampus: $t=0.23$, $\mathrm{df}=19, P=0.82)$, or p110 $\alpha$ (PFC: $t=0.16, \mathrm{df}=19, P=0.87$; hippocampus: $t=0.05, \mathrm{df}=19, P=0.96$ ) were also not different between males and females.

In addition, brain $\mathrm{pH}$ had no significant effect on PI 3kinase activity either in PFC $(r=0.11, P=0.47)$ or in hippocampus $(r=0.03, P=0.83)$. Furthermore, we found no significant effects of $\mathrm{pH}$ of the brain on mRNA levels of p85 $\alpha$ (PFC: $r=0.22, P=0.12$; hippocampus: $r=0.14$, $P=0.38)$, p85 $\beta$ ( $r=0.07, P=0.62$; hippocampus: $r=0.006$, $P=0.97), \quad$ or $\mathrm{p} 110 \alpha \quad(r=0.01, \quad P=0.92$; hippocampus: $r=0.11, P=0.49)$. We also examined the effects of brain $\mathrm{pH}$ on mRNA levels of NSE and cyclophilin but no significant effects of brain $\mathrm{pH}$ were observed on these housekeeping genes in either PFC (NSE: $r=0.18, P=0.21$; cyclophilin: $r=0.06, P=0.69$ ) or hippocampus (NSE: $r=0.11, P=0.49$; cyclophilin: $r=0.02, P=0.91$ ).

To examine whether the method of suicide had any effect on the measures of PI 3-kinase, we compared suicide 
victims who died by violent means $(n=20)$ with those who died by drug overdose/poisoning $(n=8)$. No significant differences in mRNA (PFC: p $85 \alpha, t=0.53, \mathrm{df}=26, P=0.60$; $\mathrm{p} 85 \beta, t=1.04, \mathrm{df}=26, P=0.25 ; \mathrm{p} 110 \alpha, t=0.74, \mathrm{df}=26$, $P=0.46$; hippocampus: $\mathrm{p} 85 \alpha, t=0.09, \mathrm{df}=19, P=0.93$; $\mathrm{p} 85 \beta, t=1.90, \mathrm{df}=19, P=0.07 ; \mathrm{p} 110 \alpha, t=1.09, \mathrm{df}=19$, $P=0.29$ ), protein levels (PFC: $885 \alpha, t=1.64, \mathrm{df}=26$, $P=0.11 ; \mathrm{p} 85 \beta, t=0.89, \mathrm{df}=26, P=0.38 ; \mathrm{p} 110 \alpha, t=0.03$, $\mathrm{df}=26, P=0.98$; hippocampus: $\mathrm{p} 85 \alpha, t=0.37, \mathrm{df}=19$, $P=0.71 ; \mathrm{p} 85 \beta, t=0.65, \mathrm{df}=19, P=0.52 ; \mathrm{p} 110 \alpha, t=0.88$, $\mathrm{df}=19, P=0.39$ ), or catalytic activity of PI 3-kinase (PFC: $t=0.28, \mathrm{df}=26, P=0.78$; hippocampus: $t=0.23, \mathrm{df}=19$, $P=0.82$ ) were observed between these two groups.

Effect of major depression. To examine whether the changes in various measures of PI 3-kinase in which we found significant differences between suicide subjects and normal controls were related to depression or were present in all suicide subjects, we examined the effect of major depression on these measures. For this purpose, we divided the suicide victims into those who were diagnosed with major depression and those who were diagnosed with other psychiatric disorders or had no mental illness. Of the 28 suicide subjects, 12 had major depression. In the suicide group with other psychiatric disorders $(n=16)$, there were 5 with adjustment disorder, 2 with schizoaffective disorder, 2 with bipolar disorder, 3 with drug/alcohol abuse, and 3 had no diagnosed psychiatric illness; for 2 suicide subjects the diagnosis was not available. Hippocampi were available from 21 of the 28 suicide subjects. All the normal controls and suicide subjects for the hippocampus studies were the same as described (Table 2). The hippocampi from these suicide subjects were not available: 4 suicide subjects with major depression, 2 suicide subjects whose diagnoses of psychiatric illness were not available, and 1 suicide subject with adjustment disorder. The overall MANCOVA for all dependant variables adjusted for covariates showed a significant difference for the comparison of normal controls, depressed suicide subjects, and suicide subjects with other psychiatric disorders (PFC: $\mathrm{F}=4.85, \mathrm{df}=18,64$, $P<0.001$; hippocampus: $\mathrm{F}=3.62, \mathrm{df}=18,54, P<0.001)$. The MANCOVA for the cerebellum showed no significant differences among the three groups $(\mathrm{F}=0.32$, $\mathrm{df}=10,72$, $P=0.22$ ). ANCOVA followed by pairwise between-group comparisons revealed that the catalytic activity of PI 3kinase and the mRNA and protein levels of $\mathrm{p} 85 \alpha, \mathrm{p} 85 \beta$, and p $110 \alpha$ were not different between suicide subjects with major depression and suicide subjects with other psychiatric disorders in both PFC (Table 3) and hippocampus (Table 4). However, the groups of suicide subjects with major depression and of suicide subjects with other psychiatric disorders both showed significant differences in these measures in both PFC (Table 3) and hippocampus (Table 4) when compared separately with normal control subjects.

Effect of antidepressant toxicology or prior treatment with antidepressants. To examine whether the observed changes in measures of PI 3-kinase in the suicide group were related to the presence of antidepressant(s), we compared the suicide subjects who tested positive for antidepressants during the screen at the time of death and those who did not. We did not find significant differences in mRNA (PFC: $\mathrm{p} 85 \alpha, t=0.89, \mathrm{df}=26, P=0.38 ; \mathrm{p} 85 \beta, t=0.93, \mathrm{df}=26$, $P=0.36$; $110 \alpha, t=0.41, \mathrm{df}=26, P=0.68$; hippocampus: $\mathrm{p} 85 \alpha, t=1.2, \mathrm{df}=19, \quad P=0.24 ; \mathrm{p} 85 \beta, t=0.91, \mathrm{df}=19$, $P=0.37 ; \mathrm{p} 110 \alpha, t=1.34, \mathrm{df}=19, P=0.19)$, protein levels (PFC: $\mathrm{p} 85 \alpha, t=1.14, \mathrm{df}=26, \quad P=0.26 ; \mathrm{p} 85 \beta, \quad t=0.77$, $\mathrm{df}=26, P=0.45 ; \mathrm{p} 110 \alpha, t=0.39, \mathrm{df}=26, P=0.70$; hippocampus: $\mathrm{p} 85 \alpha, t=0.05, \mathrm{df}=19, P=0.96$; $855, t=1.04$, $\mathrm{df}=19, \quad P=0.31 ; \mathrm{p} 110 \alpha, t=0.70, \mathrm{df}=19, P=0.49)$, or catalytic activity of PI 3-kinase (PFC: $t=0.16, \mathrm{df}=26$, $P=0.88$; hippocampus: $t=0.18, \mathrm{df}=19, P=0.64$ ) between those who showed a presence of antidepressants during the screen at the time of death and those who did not.

We also examined the effect of prior treatment with antidepressants on PI 3-kinase measures. Of the 12 depressed suicide subjects, 2 (\# 1 and 10) were being treated with tricyclic antidepressants 1 month prior to death and $4(\# 4,6,8,21)$ were treated with tricyclic antidepressants 3 or 6 months prior to death. Comparison of depressed suicide subjects who were treated with antidepressants $v s$ those who were untreated revealed no significant differences in PI 3-kinase activity in PFC $(t=1.51, \quad \mathrm{df}=25, \quad P=0.14)$ or hippocampus $(t=0.18$, $\mathrm{df}=18, P=0.86)$. Similarly, mRNA and protein levels of PI 3-kinase catalytic and regulatory subunits were not different between these groups either in PFC (mRNA: p $85 \alpha$, $t=0.16, \mathrm{df}=25, P=0.87 ; \mathrm{p} 85 \beta, t=1.54, \mathrm{df}=24, P=0.14$; $\mathrm{p} 110 \alpha, t=0.61, \mathrm{df}=25, P=0.54$; protein: $\mathrm{p} 85 \alpha, t=0.82$, $\mathrm{df}=25, P=0.42 ; \mathrm{p} 85 \beta, t=0.47, \mathrm{df}=25, P=0.64 ; \mathrm{p} 110 \alpha$, $t=0.65, \mathrm{df}=25, P=0.52$ ) or in hippocampus (mRNA: $\mathrm{p} 85 \alpha, t=0.57, \mathrm{df}=18, P=0.58 ; \mathrm{p} 85 \beta, t=0.33, \mathrm{df}=18$, $P=0.74 ; \mathrm{p} 110 \alpha, t=0.09, \mathrm{df}=18, P=0.92$; protein: $\mathrm{p} 85 \alpha$, $t=0.42, \mathrm{df}=18, P=0.68 ; \mathrm{p} 85 \beta, t=1.42, \mathrm{df}=18, P=0.17$; $\mathrm{p} 110 \alpha, t=0.44, \mathrm{df}=18, P=0.66)$.

Effect of alcohol toxicology. Of the 28 suicide subjects, 7 showed positive toxicology for alcohol. To examine the effect of alcohol, we compared suicide subjects who showed positive toxicology for alcohol with those who did not. Positive alcohol toxicology had no effect on PI 3-kinase activity (PFC: $t=1.51, \mathrm{df}=25, P=0.14$; hippocampus: $t=0.18, \mathrm{df}=18, P=0.86$ ) or mRNA and protein levels of PI 3-kinase catalytic and regulatory subunits in PFC (mRNA: $\mathrm{p} 85 \alpha, t=1.63, \mathrm{df}=26, P=0.11 ; \mathrm{p} 85 \beta, t=0.74$, $\mathrm{df}=26, P=0.47 ; \mathrm{p} 110 \alpha, t=0.67, \mathrm{df}=26, P=0.51$; protein: $\mathrm{p} 85 \alpha, t=0.11, \mathrm{df}=26, P=0.91 ; \mathrm{p} 85 \beta, t=0.31, \mathrm{df}=26$, $P=0.76 ; \mathrm{p} 110 \alpha, t=1.92, \mathrm{df}=26, P=0.07)$ or in hippocampus (mRNA: p $85 \alpha, t=1.13, \mathrm{df}=19, P=0.20$; p85 $\beta, t=1.12$, $\mathrm{df}=19, P=0.21 ; \mathrm{p} 110 \alpha, t=0.19, \mathrm{df}=19, P=0.85$; protein: $\mathrm{p} 85 \alpha, t=0.84, \mathrm{df}=19, \quad P=0.41 ; \mathrm{p} 85 \beta, t=0.54, \mathrm{df}=19$, $P=0.59 ; \mathrm{p} 110 \alpha, t=0.41, \mathrm{df}=19, P=0.69)$.

\section{DISCUSSION}

This study provides evidence of abnormalities of PI 3-kinase not only at the level of activation but also for the first time of differential expression patterns of catalytic vs regulatory subunits of PI 3-kinase in postmortem brain of suicide subjects compared with normal controls. We observed that catalytic activity of PI 3-kinase was significantly decreased in PFC and hippocampus of suicide 
Table 3 Effect of Major Depression on Measures of PI 3-Kinase in PFC of Suicide Subjects

\begin{tabular}{|c|c|c|c|c|c|c|c|c|c|c|c|c|}
\hline \multirow{3}{*}{ Variable } & & & \multicolumn{4}{|c|}{ Suicide subjects $(n=26)$} & \multicolumn{3}{|c|}{ Overall ANCOVA } & \multicolumn{3}{|c|}{ Multiple comparison } \\
\hline & \multicolumn{2}{|c|}{$\begin{array}{l}\text { Normal controls } \\
\qquad(n=2 I) I\end{array}$} & \multicolumn{2}{|c|}{$\begin{array}{l}\text { With a history of } \\
\text { MDD }(n=12) 2\end{array}$} & \multicolumn{2}{|c|}{$\begin{array}{c}\text { With a history of other } \\
\text { psychiatric disorders }(n=14) 3\end{array}$} & \multirow[t]{2}{*}{ df } & \multirow[t]{2}{*}{$\mathbf{F}$} & \multirow[t]{2}{*}{$P$} & \multirow[t]{2}{*}{ I vs 2} & \multirow[t]{2}{*}{ I vs 3} & \multirow[t]{2}{*}{2 vs 3} \\
\hline & Mean & SD & Mean & SD & Mean & SD & & & & & & \\
\hline $\begin{array}{l}\text { Pl3-kinase } \\
\text { activity }^{\mathrm{a}}\end{array}$ & 100 & 19.27 & 74.58 & 20.96 & 72.43 & 20.03 & 2,39 & 6.49 & 0.004 & 0.01 & 0.003 & 0.84 \\
\hline $\mathrm{p} 85 \alpha$ & 330.44 & 97.05 & 533.11 & 195.32 & 456.18 & 207.44 & 2,39 & 6.55 & 0.004 & 0.001 & 0.05 & 0.11 \\
\hline $\mathrm{p} 85 \beta$ & 2813.90 & 561.79 & 2170.66 & 195.43 & 1913.76 & 497.06 & 2, 39 & 17.64 & $<0.001$ & 0.001 & $<0.001$ & 0.19 \\
\hline$p \mid 10 \alpha$ & 967.57 & 382.11 & 566.70 & 241.53 & 726.14 & 203.10 & 2, 39 & 3.44 & 0.04 & 0.02 & 0.04 & 0.43 \\
\hline $\mathrm{p} \mid 10 \beta$ & 78225.79 & | $483 \mid .38$ & 78706.28 & 27216.34 & 81439.54 & |3697.|| & 2,39 & 0.05 & 0.95 & 0.96 & 0.76 & 0.84 \\
\hline$p|| 0 \alpha$ & 100 & 16.77 & 82.33 & 11.80 & 75.36 & 17.84 & 2,39 & 8.01 & 0.001 & 0.01 & $<0.001$ & 0.06 \\
\hline $\mathrm{pl} 10 \beta$ & 100 & 17.33 & 93.25 & 14.05 & 97.28 & 22.61 & 2,39 & 0.81 & 0.45 & 0.21 & 0.82 & 0.35 \\
\hline
\end{tabular}

a Percent of control. Data were analyzed using multivariate analysis of covariance (MANCOVA). Overall MANCOVA (Pillai's Trace test) was found to be statistically significant $(F=4.85, \mathrm{df}=18,64, \mathrm{P}<0.00 \mathrm{I})$. The data were then subjected to analysis of covariance (ANCOVA) followed by pairwise between-group comparisons. A total of nine dependent variables (PI 3-kinase activity, and mRNA and protein levels of $\mathrm{p} 85 \alpha, \mathrm{p} 85 \beta, \mathrm{p}|\mathrm{IO} \alpha, \mathrm{p}| \mathrm{IO} \beta$ ) were considered during multivariate analysis. Age, gender, $\mathrm{pH}$ of the brain, race, and postmortem interval were used as covariates.

${ }^{\mathrm{b}}$ Attomol/ $\mu \mathrm{g}$ total RNA.

Table 4 Effect of Major Depression on Measures of PI 3-Kinase in Hippocampus of Suicide Subjects

\begin{tabular}{|c|c|c|c|c|c|c|c|c|c|c|c|c|}
\hline \multirow{3}{*}{ Variable } & & & \multicolumn{4}{|c|}{ Suicide subjects $(n=2 I)$} & \multicolumn{3}{|c|}{ Overall ANCOVA } & \multicolumn{3}{|c|}{ Multiple comparison } \\
\hline & \multicolumn{2}{|c|}{$\begin{array}{l}\text { Normal controls } \\
\quad(n=21) I\end{array}$} & \multicolumn{2}{|c|}{$\begin{array}{l}\text { With a history of } \\
\text { MDD }(n=8) 2\end{array}$} & \multicolumn{2}{|c|}{$\begin{array}{c}\text { With a history of other } \\
\text { psychiatric disorders }(n=13) 3\end{array}$} & \multirow[t]{2}{*}{ df } & \multirow[t]{2}{*}{$\mathbf{F}$} & \multirow[t]{2}{*}{$P$} & \multirow[t]{2}{*}{ I vs 2} & \multirow[t]{2}{*}{ I vs 3} & \multirow[t]{2}{*}{2 vs 3} \\
\hline & Mean & SD & Mean & SD & Mean & SD & & & & & & \\
\hline $\begin{array}{l}\text { PI3-kinase } \\
\text { Activity }^{\mathrm{a}}\end{array}$ & 100 & 15.66 & 71.87 & 21.53 & 73.15 & 27.61 & 2,34 & 7.32 & 0.002 & 0.04 & 0.001 & 0.56 \\
\hline \multicolumn{13}{|c|}{ mRNA Levels ${ }^{b}$} \\
\hline $\mathrm{p} 85 \alpha$ & 257.09 & 77.40 & 451.50 & 144.80 & 443.96 & 164.39 & 2,34 & 7.84 & 0.002 & 0.01 & 0.001 & 0.84 \\
\hline $\mathrm{p} 85 \beta$ & 1846.98 & 580.54 & 1118.32 & 598.97 & 1260.59 & 650.47 & 2,34 & 10.22 & $<0.001$ & $<0.00$ । & 0.01 & 0.07 \\
\hline$p \mid 10 \alpha$ & 845.31 & 126.19 & 617.37 & 190.15 & 556.50 & 206.54 & 2,34 & 9.56 & 0.001 & 0.05 & $<0.00 \mid$ & 0.22 \\
\hline$p \mid 10 \beta$ & 18570.28 & $50 \mid 4.83$ & $186 \mid 0.63$ & 4981.05 & | 5689.69 & 3122.95 & 2,34 & 1.09 & 0.35 & 0.87 & 0.16 & 0.28 \\
\hline$p \mid 10 \alpha$ & 100 & 23.21 & 65.12 & 15.80 & 68.08 & 17.60 & 2,34 & 8.94 & 0.001 & 0.01 & 0.001 & 0.81 \\
\hline$p \mid 10 \beta$ & 100 & 18.45 & 94.87 & 19.59 & 98.61 & $|8.4|$ & 2,34 & 0.03 & 0.97 & 0.83 & 0.88 & 0.94 \\
\hline
\end{tabular}

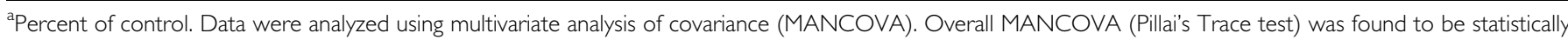
significant $(F=3.62, \mathrm{df}=18,54, \mathrm{P}<0.00 \mathrm{I})$. The data were then subjected to analysis of covariance (ANCOVA) followed by pairwise between-group comparisons A total of nine dependent variables (PI 3-kinase activity, and mRNA and protein levels of $p 85 \alpha, p 85 \beta, p|| 0 \alpha, p|| 0 \beta$ ) were considered during multivariate analysis. Age, gender, $\mathrm{pH}$ of the brain, race, and postmortem interval were used as covariates.

${ }^{\mathrm{b}}$ Attomol/ $\mu \mathrm{g}$ total RNA.

subjects. On the other hand, whereas mRNA and protein levels of regulatory $\mathrm{p} 85 \beta$ and catalytic $\mathrm{p} 110 \alpha$ were decreased, expression levels of regulatory p85 $\alpha$ were increased. No significant changes in expression levels of p110 $\beta$ were found. None of the PI 3-kinase measures showed any significant changes in cerebellum. Our study 
thus not only shows that there is decreased activation of PI 3-kinase but also that specific catalytic and regulatory subunits of PI 3-kinase are differentially expressed in PFC and hippocampus of suicide subjects compared with normal controls. Moreover, these changes appear to be brain region specific, as no change was observed in the cerebellum. In addition, we observed that changes in PI 3-kinase were present in all suicide subjects whether they were diagnosed with major depression or other psychiatric illnesses, which further suggests that these changes are related to suicide rather than some specific psychopathology.

A number of studies have shown that all catalytic and regulatory isoforms of class IA PI 3-kinase, except p110 $\delta$, are highly expressed in the central nervous system (Pons et al, 1995; Antonetti et al, 1996; Fruman et al, 1996; Inukai et al, 1997). When we examined the relative mRNA distribution of catalytic and regulatory subunit isoforms of PI 3-kinase, an interesting pattern of expression emerged in the human PFC and hippocampus. It was observed that the mRNA expression of $\mathrm{p} 85 \beta$ was much higher than that of p $85 \alpha$ in both PFC and hippocampus. Although the levels of p $85 \alpha$ were similar in PFC and hippocampus, the level of p85 $\beta$ was higher in PFC than hippocampus. Our finding is different than those reported in murine brain, where similar expression levels of both $\mathrm{p} 85 \alpha$ and $\mathrm{p} 85 \beta$ were found in cerebral cortex and hippocampus (Horsch and Kahn, 1999). Our comparative analysis of $\mathrm{p} 110 \alpha$ in PFC and hippocampus showed that the expression levels of $\mathrm{p} 110 \alpha$ were almost the same in PFC and hippocampus, whereas expression of p1 $10 \beta$ was much higher in PFC than hippocampus. On the other hand, $110 \beta$ was more highly expressed in both PFC and hippocampus than $\mathrm{p} 110 \alpha$. It is interesting to note that co-expression of all isoforms of catalytic and regulatory subunits has been reported in neurons (Shin et al, 1998). Our findings of differential expression of regulatory and catalytic subunit isoforms in PFC and hippocampus suggest the possibility that different regulatory mechanisms for the expression of each subunit isoform may exist. Whether the higher expression levels of $\mathrm{p} 85 \beta$ and $\mathrm{p} 110 \beta$ in both PFC and hippocampus are associated with different substrate affinities or for specific functional capabilities, remains to be elucidated.

The mechanism of the reduced catalytic activity of PI 3-kinase in postmortem brain of suicide subjects is not clear at this time but appears to be related to the altered expression of catalytic p110 $\alpha$ and/or regulatory p85 subunits. It has been shown that regulatory p 85 not only connects p110 catalytic subunits to activate transmembrane receptors, it also stabilizes the catalytic subunit. Interestingly, p85 acts as an inhibitor of p110 $\alpha$ catalytic activity, and in many cell types, p85 is stoichiometrically in excess of p110, and free p85 can act as a dominant negative to inhibit PI3-kinase signaling (Ueki et al, 2003). Our findings of increased expression of $\mathrm{p} 85 \alpha$ interestingly indicate that the decreased catalytic activity in postmortem brain of suicide subjects could possibly be associated with this increase, although the decrease in the $\mathrm{p} 85 \beta$ subunit contradicts such an association. The possibility that $\mathrm{p} 85 \alpha$ and $\mathrm{p} 85 \beta$ subunits may be localized in different intracellular compartments (eg membrane $v s$ cytosol), however, cannot be ruled out, as we determined the catalytic activity in total lysate. Additional mechanisms may also be responsible for such a decrease. It has been shown that in addition to catalyzing D3 phosphorylation of PIs, p110 subunits possess ser/thr kinase activity, and by phosphorylating $\mathrm{p} 85 \alpha$ on a $\operatorname{Ser}^{608}$, $\mathrm{p} 110 \alpha$ can reduce the kinase activity of heterodimeric $\mathrm{p} 110 \alpha / \mathrm{p} 85 \alpha$ (Carpenter et al, 1993; Dhand et al, 1994). In addition, PI 3-kinase catalytic subunits can be activated by the small GTP-binding protein Ras through SHC and Grb-2 (Rodriquez-Viciana et al, 1994). Whether such mechanisms exist in the observed downregulation of PI 3-kinase activity in postmortem brain of suicide subjects is not known and needs further investigation. It is interesting to note that the synthetic glucocorticoid dexamethasone causes an increase in expression of the p85 subunit (Giorgino et al, 1997). Since stress is one of the major factors in suicide, and since components of the hypothalamic-pituitary-adrenal axis have been shown to be altered in postmortem brain of suicide subjects (Mann and Currier, 2007), regulation of PI3-kinase subunits by glucocorticoids cannot be ruled out.

The functional significance of altered specific catalytic and regulatory PI 3-kinase subunits in postmortem brain of suicide subjects remains to be elucidated; however, these alterations may have significant physiological consequences in the brain. In fact, both its enzymatic activity and interaction with many target proteins makes PI 3-kinase a multifunctional enzyme that contributes to the pivotal role of PI 3-kinase signal transduction in controlling numerous cellular functions. PI3-kinase is the major regulator of neurotrophin-mediated survival in cortical, hippocampal, sensory, and motor neurons (Yao and Cooper, 1995; Skaper et al, 1998; Dolcet et al, 1999; Hetman et al, 1999; Liot et al, 2004), as well as glia (Rodgers and Theibert, 2002). One of the most important targets of PI 3-kinase is Akt (Vanhaesebroeck and Alessi, 2000; Patapoutian and Reichardt, 2001), which is activated after binding with the PI 3-kinase lipid product $\mathrm{PI}-3,4,5-\mathrm{P}_{3}$ or through phosphorylation by another target of PI 3-kinase, that is, PI-dependent kinase-1 (PDK-1) (Alessi et al, 1997). Akt, in turn, inhibits Forkhead transcription factors, responsible for inducing expression of death genes; phosphorylates and therefore inhibits glycogen synthase kinase- $3 \beta$ activity, involved in neuronal apoptosis (Patapoutian and Reichardt, 2001); induces expression of survival genes, such as $\mathrm{Bcl}-2$ and $\mathrm{Bcl}-\mathrm{x}_{\mathrm{L}}$, by activating cyclicAMP response element binding protein and nuclear factor- $\kappa \mathrm{B}$ (Downward, 2004); phosphorylates and deactivates proapoptotic Bad (Datta et al, 2000) and caspase-9 (Zhou et al, 2000); and blocks proapoptotic action of the p75 neurotrophin receptor (Miller and Kaplan, 2001). Interestingly, activation of PDK-1 leads to phosphorylation and activation of protein kinase $\mathrm{C}$ (PKC) family members (Chou et al, 1998; Le Good et al, 1998), and PI-3,4,5- $\mathrm{P}_{3}$ in response to growth factor activation enhances phospholipase C (PLC) $\gamma$ activity (Falasca et al, 1998). It is pertinent to mention that we have found altered activation of PKC in postmortem brain of suicide subjects (Pandey et al, 2004) and that PLC $\gamma$ may have an important role in depressive behavior (Dwivedi et al, 2005b).

Recently, Martin-Pena et al (2006) showed that PI 3-kinase controls cell size and that persistent PI 3-kinase activity is necessary for synapse maintenance. In addition, PI 3-kinase is important in dendritic formation in cortical and hippocampal neurons (Leemhuis et al, 2004; Dijkhuizen and Ghosh, 2005). A number of studies suggest that subjects 
with affective disorders show morphological changes in the brain, including atrophy of neurons and reduction in volumes of PFC and hippocampus (Sheline et al, 1996; Drevets et al, 1997, 1999; Bremner et al, 2000). Several postmortem brain studies also suggest reductions in cell number and in density and size of cortical and hippocampal neurons (Rajkowska, 1997, 2000; Benes et al, 1998; Rajkowska et al, 1999, 2001). Altered brain structures have also been demonstrated in brain of suicide subjects (Altschuler et al, 1990; Rajkowska, 1997; Rajkowska et al, 2001). In addition, synaptic loss has been correlated with the cognitive disturbances associated with mood disorders (Duman, 2002; Fossati et al, 2004; Kolomeets et al, 2005). Our findings that activation of PI 3-kinase is reduced in PFC and hippocampus of suicide subjects suggest the possibility that the altered brain structure in depressed and suicide subjects could be a consequence of reduced PI 3-kinase activation.

Some studies suggest that PI3-kinase crosstalks to extracellular signal-regulated kinase (ERK) signaling. It has been shown that PI 3-kinase through its protein kinase activity, regulates Ras, Raf, or ERK kinase (MEK) (Hu et al, 1995; Pandey et al, 1999; Bondeva et al, 1998). PI 3-kinase can directly activate MEK through protein phosphorylation Bondeva et al, 1998), or PDK-1 can directly bind and activate MEK (Sato et al, 2004). In fact, recently Ou and Gean (2006) showed that PI 3-kinase inhibitors attenuate BDNF-induced ERK phosphorylation in rat amygdala, indicating that PI 3-kinase is an upstream regulator of MAP kinase activation. Recently, we observed altered ERK$1 / 2$ signaling at multiple levels, including alterations in activation and expression of ERK-1/2 and B-Raf in postmortem brain of suicide subjects (Dwivedi et al, 2001, 2006). It is quite possible that ERK and PI 3-kinase signaling pathways may be regulating physiological functions in a coordinated fashion and that alterations in the signaling in these two pathways may be important in the pathophysiologic process of suicide.

In conclusion, our study clearly indicates abnormalities in activation and expression of PI 3-kinase in postmortem brain of suicide subjects. Recently it was reported that PI 3-kinase activity is decreased in occipital cortex of suicide subjects (Hsiung et al, 2003) and that ECS (Altar et al, 2004) or long-term lithium treatment (Chalecka-Franaszek and Chuang, 1999) increases PI 3-kinase activity. Given the role of PI 3-kinase in a plethora of biological functions, these and our present findings appear to be quite significant and suggest the possibility that dysfunction of PI 3-kinase signaling may be important in the pathophysiologic mechanisms of suicide.

\section{ACKNOWLEDGEMENTS}

This research was supported by NIMH R0168777, NARSAD, and the American Foundation for Suicide Prevention to Dr Dwivedi, NIMH RO1MH48153 to Dr Pandey, and NIMH R01MH60744 to Dr Roberts. We thank Prof. Robert Gibbons for his help analyzing data. We also thank Ms Miljana Petkovic and Ms Barbara Brown for their help in organizing the brain tissue, and members of the Maryland Brain Collection for their efforts, particularly in family interviews and dissection. We are grateful for the cooperation of the Office of the Chief Medical Examiner in Baltimore, MD, USA.

\section{DISCLOSURE/CONFLICT OF INTEREST}

The authors declare that, except for income received from the primary employer, no financial support or compensation has been received from any individual or corporate entity over the past 3 years for research or professional services and that there are no personal financial holdings that could be perceived as constituting a potential conflict of interest.

\section{REFERENCES}

Alessi DR, Deak M, Casamayor A, Caudwell FB, Morrice N, Norman DG et al (1997). 3-Phosphoinositide-dependent protein kinase-1 (PDK1): structural and functional homology with the Drosophila DSTPK61 kinase. Curr Biol 7: 776-789.

Altar CA, Laeng P, Jurata LW, Brockman JA, Lemire A, Bullard L et al (2004). Electroconvulsive seizures regulate gene expression of distinct neurotrophic signaling pathways. J Neurosci 24: 2277-2677.

Altschuler DL, Casanova MF, Goldberg TE, Kleinman JE (1990). The hippocampus and parahippocampus in schizophrenia, suicide and control brains. Arch Gen Psychiatry 47: 1029-1034.

Antonetti DA, Algenstaedt P, Kahn CR (1996). Insulin receptor substrate 1 binds two novel splice variants of the regulatory subunit of phosphatidylinositol 3-kinase in muscle and brain. Mol Cell Biol 16: 2195-2203.

Benes FM, Kwok EW, Vincent SL, Todtankopf MS (1998). A reduction of nonpyramidal cells in sector CA2 of schizophrenics and manic depressives. Biol Psychiatry 15: 88-97.

Bondeva T, Pirola L, Bulgarelli-Leva G, Rubio I, Wetzker R, Wymann MP (1998). Bifurcation of lipid and protein kinase signals of PI3Kgamma to the protein kinases PKB and MAPK. Science 282: 293-296.

Bremner JD, Narayan M, Anderson ER, Stalb LH, Miller HL, Charney DS (2000). Hippocampal volume reduction in major depression. Am J Psychiatry 48: 971-975.

Cantley LC (2002). The phosphoinositide 3-kinase pathway. Science 296: 1655-1657.

Carpenter CL, Auger KR, Duckworth BC, Hou WM, Schaffhausen B, Cantley LC (1993). A tightly associated serine/threonine protein kinase regulates phosphoinositide 3-kinase activity. $\mathrm{Mol}$ Cell Biol 13: 1657-1665.

Chalecka-Franaszek E, Chuang DM (1999). Lithium activates the serine/threonine kinase Akt-1 and suppresses glutamate-induced inhibition of Akt-1 activity in neurons. Proc Natl Acad Sci USA 96: 8745-8750.

Chou MM, Hou W, Johnson J, Graham LK, Lee MH, Chen CS et al (1998). Regulation of protein kinase C zeta by PI 3-kinase and PDK-1. Curr Biol 8: 1069-1077.

Clayton PJ (1985). Suicide. Psychiatr Clin North Am 8: 203-214.

Crowder RJ, Freeman RS (1998). Phosphatidylinositol 3-kinase and Akt protein kinase are necessary and sufficient for the survival of nerve growth factor-dependent sympathetic neurons. J Neurosci 18: 2933-2943.

Datta SR, Dudek H, Tao X, Masters S, Fu H, Gotoh Y et al (2000). Akt phosphorylation of BAD couples survival signals to the cellintrinsic death machinery. Cell 91: 231-241.

Dhand R, Hiles I, Panayotou G, Roche S, Fry MJ, Gout I et al (1994). PI 3-kinase is a dual specificity enzyme: autoregulation by an intrinsic protein-serine kinase activity. $E M B O J$ 13: 522-533. 
Dijkhuizen PA, Ghosh A (2005). Regulation of dendritic growth by calcium and neurotrophin signaling. Prog Brain Res 147: 17-27. Dolcet X, Egea J, Soler RM, Martin-Zanca D, Comella JX (1999). Activation of phosphatidylinositol 3-kinase, but not extracellular-regulated kinases, is necessary to mediate brain-derived neurotrophic factor-induced motoneuron survival. J Neurochem 73: 521-531.

Downes CP, Gray A, Lucocq JM (2005). Probing phosphoinositide functions in signaling and membrane trafficking. Trends Cell Biol 15: 259-268.

Downward J (2004). PI 3-kinase, Akt and cell survival. Semin Cell Dev Biol 15: 177-182.

Drevets WC, Gadde KM, Krishman KR (1999). Neuroimaging studies of mood disorders. In: Charney DS, Nestler EJ, Bunney BS (eds). Neurobiology of Mental Illness. Oxford University Press: New York, pp 394-418.

Drevets WC, Price JL, Simpson Jr JR, Todd RD, Reich T, Vannier $M$ et al (1997). Subgenual prefrontal cortex abnormalities in mood disorders. Nature 386: 824-827.

Duman RS (2002). Pathophysiology of depression: the concept of synaptic plasticity. Eur Psychiatry 17: 306-310.

Dwivedi Y, Conley RR, Roberts RC, Tamminga CA, Pandey GN (2002). Alpha subunits of $G$ proteins in the prefrontal cortex of teenage and adult suicide victims. Neuropsychopharmacology 27: 499-517.

Dwivedi Y, Mondal AC, Rizavi HS, Conley RR (2005a). Suicide brain is associated with decreased expression of neurotrophins. Biol Psychiatry 58: 315-324.

Dwivedi Y, Mondal AC, Rizavi HS, Shukla PK, Pandey GN (2005b). Single and repeated stress-induced modulation of phospholipase $\mathrm{C}$ catalytic activity and expression: role in $\mathrm{LH}$ behavior. Neuropsychopharmacology 30: 473-483.

Dwivedi Y, Rao JS, Rizavi HS, Kotawski J, Conley RR, Roberts RC et al (2003b). Abnormal expression and functional characteristics of cyclic adenosine monophosphate response element binding protein in postmortem brain of suicide subjects. Arch Gen Psychiatry 60: 273-282.

Dwivedi Y, Rizavi HS, Conley RR, Pandey GN (2006). ERK MAP kinase signaling in post-mortem brain of suicide subjects: differential regulation of upstream Raf kinases Raf-1 and B-Raf. Mol Psychiatry 11: 86-98.

Dwivedi Y, Rizavi HS, Conley RR, Roberts RC, Tamminga CA, Pandey GN (2003a). Altered gene expression of brain-derived neurotrophic factor and receptor tyrosine kinase B in postmortem brain of suicide subjects. Arch Gen Psychiatry 60: 804-815.

Dwivedi Y, Rizavi HS, Roberts RC, Conley RC, Tamminga CA, Pandey GN (2001). Reduced activation and expression of ERK1/2 MAP kinase in the post-mortem brain of depressed suicide subjects. J Neurochem 77: 916-928.

Engelman JA, Luo J, Cantley LC (2006). The evolution of phosphatidylinositol 3-kinase as regulators of growth and metabolism. Nature 7: 606-619.

Falasca M, Logan S, Lehto VP, Baccante G, Lemmon MA, Schlessinger J (1998). Activation of phospholipase C gamma by PI 3-kinase-induced $\mathrm{PH}$ domain-mediated membrane targeting. EMBO J 17: 414-422.

Fossati P, Radtchenko A, Boyer P (2004). Neuroplasticity: from MRI to depressive symptoms. Eur Neuropsychopharmacol 14: S503-S510.

Fruman DA, Cantley LC, Carpenter CL (1996). Structural organization and alternative splicing of the murine phosphoinositide 3-kinase p85á gene. Genomics 37: 113-121.

Fruman DA, Meyers RE, Cantley LC (1998). Phosphoinositide kinases. Annu Rev Biochem 67: 481-507.

George MS, Ketter TA, Post RM (1994). Prefrontal cortex dysfunction in clinical depression. Depression 2: 59-72.

Giorgino F, Pedrini MT, Matera L, Smith RJ (1997). Specific increase in p85a expression in response to dexamethasone is associated with inhibition of insulin-like growth factor-1 stimulated phosphatidylinositol 3-kinase activity in cultured muscle cells. J Biol Chem 272: 7455-7463.

Harrison PJ, Heath PR, Eastwood SL, Burnet PW, McDonald B, Pearson RC (1995). The relative importance of premortem acidosis and postmortem interval for human brain gene expression studies: selective mRNA vulnerability and comparison with their encoded proteins. Neurosci Lett 200: 151-154.

Hawkins PT, Jackson TR, Stephens LR (1992). Platelet-derived growth factor stimulates synthesis of PtdIns $(3,4,5) \mathrm{P} 3$ by activating a PtdIns(4,5)P2 3-OH kinase. Nature 358: 157-159.

Hetman M, Kanning K, Cavanaugh JE, Xia Z (1999). Neuroprotection by brain-derived neurotrophic factor is mediated by extracellular signal-regulated kinase and phosphatidylinositol 3-kinase. J Biol Chem 274: 22569-22580.

Hiles ID, Otsu M, Volinia S, Fry MJ, Gout I, Dhand R et al (1992). Phosphatidylinositol 3-kinase: structure and expression of the $110 \mathrm{kDa}$ catalytic subunit. Cell 70: 419-429.

Horsch D, Kahn CR (1999). Region-specific mRNA expression of phosphatidylinositol 3-kinase regulatory isoforms in the central nervous system of C57BL/6J mice. J Comp Neurol 415: 105-120.

Hsiung SC, Adlersberg M, Arango V, Mann JJ, Tamir H, Liu KP (2003). Attenuated 5-HT1A receptor signaling in brains of suicide victims: involvement of adenylyl cyclase, phosphatidylinositol 3-kinase, Akt and mitogen-activated protein kinase. $J$ Neurochem 87: 182-194.

Hu P, Mondino A, Skolnik EY, Schlessinger J (1993). Cloning of a novel, ubiquitously expressed human phosphatidylinositol 3kinase and identification of its binding site on p85. Mol Cell Biol 13: 7677-7688.

Hu QJ, Klippel A, Muslin AJ, Fantl WJ, Williams LT (1995). Rasdependent induction of cellular-responses by constitutively active phosphatidylinositol-3 kinase. Science 268: 100-102.

Inukai K, Funaki M, Ogihara T, Katagiri H, Kanda A, Anai M et al (1997). p85á gene generates three isoforms of regulatory subunit for phosphatidylinositol 3-kinase (PI3-kinase), p50á, p55á, and p85á, with different PI 3-kinase activity elevating responses to insulin. J Biol Chem 272: 7873-7882.

Kaplan D, Miller F (2001). Neurotrophin signal transduction in the nervous system. Curr Opin Neurobiol 10: 381-391.

Kolomeets NS, Orlovskaya DD, Rachmanova VI, Uranova NA (2005). Ultrastructural alterations in hippocampal mossy fiber synapses in schizophrenia: a postmortem morphometric study. Synapse 57: 47-55.

Le Good JA, Ziegler WH, Parekh DB, Alessi DR, Cohen P, Parker PJ (1998). Protein kinase C isotypes controlled by phosphoinositide 3-kinase through the protein kinase PDK1. Science 281: 2042-2045.

Leemhuis J, Mayer U, Barth H, Schmidt G, Meyer DK (2004). The small GTPase Rac is involved in clustering of hippocampal neurons and fasciculation of their neurites. Arch Pharmacol 370: 211-222.

Lin CH, Yeh SH, Lin CH, Lu KT, Leu TH, Chang WC et al 2001)). A role for the PI-3 kinase signaling pathway in fear conditioning and synaptic plasticity in the amygdala. Neuron 31: 841-851.

Liot G, Gabriel C, Cacquevel M, Ali C, MacKenzie ET, Buisson A et al (2004). Neurotrophin-3-induced PI-3 kinase/Akt signaling rescues cortical neurons from apoptosis. Exp Neurol 187: 38-46.

Lowry OH, Rosebrough NJ, Farr AL, Randall RJ (1951). Protein measurement with the folic phenol reagent. J Biol Chem 193: 266-275.

Mann JJ, Currier D (2007). A review of prospective studies of biologic predictors of suicidal behavior in mood disorders. Arch Suicide Res 11: 3-16.

Martin-Pena A, Acebes A, Rodriguez J-R, Sorribes A, Depolavieja GG, Fernandez-Funez P et al (2006). Age-independent synaptogenesis by phosphoinositide 3 kinase. J Neurosci 26: 10199-10208. 
Miller F, Kaplan D (2001). Neurotrophin signal pathways regulating neuronal apoptosis. Cell Mol Life Sci 58: 1045-1053.

Monk M (1987). Epidemiology of suicide. Epidemiol Rev 9: 51-69.

Okkenhaug K, Vanhaesebroeck B (2001). New responsibilities for the PI3K regulatory subunit p85 alpha. Sci STKE 65: PE1.

Ou L-C, Gean P-W (2006). Regulation of amygdala-dependent learning by brain-derived neurotrophic factor is mediated by extracellular signal-regulated kinase and phosphatidylinositol-3kinase. Neuropsychopharmacology 31: 287-296.

Pandey GN, Dwivedi Y, Rizavi HS, Ren X, Conley RR (2004). Decreased catalytic activity and expression of protein kinase $C$ isozymes in teenage suicide victims: a postmortem brain study. Arch Gen Psychiatry 61: 685-693.

Pandey SK, Theberge JF, Bernier M, Srivastava AK (1999). Phosphatidylinositol-3 kinase requirement in activation of the ras/C-raf-1/MEK/ERK and p70(s6k) signaling cascade by the insulinomimetic agent vanadyl sulfate. Biochemistry 38: 14, 667-14,675.

Patapoutian A, Reichardt L (2001). Trk receptors: mediators of neurotrophin action. Curr Opin Neurobiol 11: 272-280.

Pons S, Asano T, Glasheen EM, Miralpeix M, Zhang Y, Fisher TL et al (1995). The structure and function of $\mathrm{p} 55^{\mathrm{PIR}}$ reveal a new regulatory subunit for phosphatidylinositol 3-kinase. Mol Cell Biol 15: 4453-4465.

Rajkowska G (1997). Morphometric methods for studying the prefrontal cortex in suicide victims and psychiatric patients. $A n n$ NY Acad Sci USA 836: 253-268.

Rajkowska G (2000). Postmortem studies in mood disorders indicate altered numbers of neurons and glial cells. Biol Psychiatry 48: 766-777.

Rajkowska G, Halaris A, Selemon LD (2001). Reductions in neuronal and glial density characterize the dorsolateral prefrontal cortex in bipolar disorder. Biol Psychiatry 49: 741-752.

Rajkowska G, Miguel-Hidalgo JJ, Wei J, Dilley G, Pittman SD, Meltzer HY et al (1999). Morphometric evidence for neuronal and glial prefrontal cell pathology in major depression. Biol Psychiatry 45: 1085-1098.

Rodgers EE, Theibert AB (2002). Functions of PI 3-kinase in development of the nervous system. Int J Dev Neurosci 20: 187-197.

Rodriquez-Viciana P, Warne PH, Dhand R, Vanhaesebroeck B, Gout I, Fry MJ et al (1994). Phosphatidylinositol-3-OH kinase as a direct target of Ras. Nature 370: 527-532.

Sala M, Perez J, Soloff P, Ucelli di Nemi S, Caverzasi E, Sores JC et al (2004). Stress and hippocampal abnormalities in psychiatric disorders. Eur Neuropsychopharmacol 14: 393-405.
Salzman S, Endicott J, Clayton P, Winokur G (1983). Diagnostic Evaluation After Death (DEAD). Neuroscience Research Branch, National Institute of Mental Health: Rockville, MD.

Sato S, Fujita N, Tsuruo T (2004). Involvement of 3-phosphatidylinositol-dependent protein kinase- 1 in the MEK/MAPK signal transduction pathway. J Biol Chem 279: 33759-33767.

Segal RA (2003). Selectivity in neurotrophin signaling: theme and variations. Annu Rev Neurosci 26: 299-330.

Sheline YI, Warry P, Gado MH, Csernansky JC, Vannier MW (1996). Hippocampal atrophy in recurrent major depression. Proc Natl Acad Sci USA 93: 3908-3913.

Shin BC, Suzuki M, Inukai K, Anai M, Asano T, Takata K (1998). Multiple isoforms of the regulatory subunit for phosphatidylinositol 3-kinase (PI3-kinase) are expressed in neurons in the rat brain. Biochem Biophys Res Commun 246: 313-319.

Skaper SD, Floreani M, Negro A, Facci L, Giusti P (1998). Neurotrophins rescue cerebellar granule neurons from oxidative stress-mediated apoptotic death: selective involvement of phosphatidylinositol 3-kinase and the mitogen-activated protein kinase pathway. J Neurochem 70: 1859-1868.

Songyang Z, Shoelson SE, Chaudhuri M, Gish G, Pawson T, Haser WG et al (1993). SH2 domains recognize specific phosphopeptide sequences. Cell 72: 767-778.

Spitzer RL, Williams JBW, Gibbon M, First MD (1995). Structural Clinical Interview for DSM-IV (SCID),. New York State Psychiatric Institute Biometrics Research: New York, NY.

Sweatt JD (2004). Hippocampal function in cognition. Psychopharmacology 174: 99-110.

Ueki K, Fruman DA, Yballe CM, Fasshauer M, Klein J, Asano T et al (2003). Positive and negative roles of p85 alpha and p85 beta regulatory subunits of phosphoinositide 3-kinase in insulin signaling. J Biol Chem 278: 48453-48466.

Vanhaesebroeck B, Alessi DR (2000). The PI3K-PDK1 connection: more than just a road to PKB. Biochem J 346: 561-576.

Vanhaesebroeck B, Ali K, Bilancio A, Geering B, Foukas LC (2005). Signaling by PI3K isoforms: insights from gene-targeted mice. Trends Biochem Sci 30: 194-204.

Wymann MP, Zvelebil M, Laffargue M (2003). Phosphoinositide 3-kinase signaling - which way to target? Trends Pharmacol Sci 24: 366-376.

Yao R, Cooper GM (1995). Requirement for phosphatidylinositol 3-kinase and the prevention of apoptosis by nerve growth factor. Science 267: 2003-2006.

Zhou H, Li XM, Meinkoth J, Pittman RN (2000). Akt regulates cell survival and apoptosis at a post-mitochondrial level. J Cell Biol 151: 483-494. 